\title{
Promyelocytic Leukemia (PML) gene regulation: implication towards curbing oncogenesis
}

\author{
Neerajana Datta', Saimul Islam², Uttara Chatterjee ${ }^{3}$, Sandip Chatterjee ${ }^{3}$, Chinmay K. Panda ${ }^{2}$ and Mrinal K. Ghosh ${ }^{1}$
}

\begin{abstract}
Dysregulation of PML, a significant tumor suppressor is linked with cancers of different histological origins, with a decreased expression observed with a higher tumor grade. This necessitates studying the mechanisms to maintain a stable expression of PML. However much less is known about the transcriptional regulation of PML, more so in the context of breast carcinoma. ER $\beta$ has emerged as a critical factor in understanding breast cancer, especially since a huge proportion of breast cancers are $\mathrm{ERa}^{-}$and thus insensitive to tamoxifen therapy. This study aims to uncover an unidentified mechanism of PML gene regulation and its stabilization in breast cancer via ER $\beta$ signalling and the impact on cellular apoptosis. We found that clinical expression of PML positively correlates with that of ER $\beta$ both in normal and breast carcinoma samples and inversely correlates with markers of cellular proliferation, hinting towards a possible mechanistic interdependence. Both mRNA and protein expression of PML were increased in response to ER $\beta$ overexpression on multiple human breast cancer cell lines. Mechanistically, luciferase reporter assays and chromatinimmunoprecipitation assays demonstrated that ER $\beta$ can interact with the PML promoter via ERE and AP1 sites to enhance its transcription. ER $\beta$ induced stable PML expression causes a decline of its target protein Survivin and simultaneously provides a stable docking platform leading to stabilisation of its target Foxo3a, further causing transcriptional upregulation of pro-apoptotic factors p21 and p27. Immunohistochemical analyses of cancer and normal breast tissues and functional assays conducted corroborated the findings. Collectively, our study identifies ER $\beta$ signalling as a novel mechanism for PML gene regulation in $\mathrm{ERa}^{-}$breast cancer. It also reveals bi-directional downstream effect in which 'ERß-PML-(Foxo3a/Survivin)' network acts as a therapeutic axis by suppressing cellular survival and promoting cellular apoptosis in breast carcinoma.
\end{abstract}

\section{Introduction}

Promyelocytic Leukemia Protein (PML) is an essential component of PML Nuclear bodies (PML-NBs) where it plays a vital role in their formation and stability. PMLNBs act as cellular organizing centers for the coordinated regulation of various processes such as transcriptional regulation, post-translational modifications, DNA

\footnotetext{
Correspondence: Mrinal K. Ghosh (mrinal.res@gmail.com)

${ }^{1}$ Cancer Biology and Inflammatory Disorder Division, Council of Scientific and Industrial Research-Indian Institute of Chemical Biology (CSIR-IICB), TRUE Campus, CN-6, Sector-V, Salt Lake, Kolkata-700091 \& 4, Raja S.C. Mullick Road, Jadavpur, Kolkata 700032, India

${ }^{2}$ Department of Oncogene Regulation, Chittaranjan National Cancer Institute, 37, S.P. Mukherjee Road, Kolkata 700026, India

Full list of author information is available at the end of the article.

Edited by S. He
}

replication, apoptosis, senescence, cell cycle regulation and DNA damage repairs ${ }^{1}$. Hence, since its discovery PML is implicated in playing a role in carcinogenesis and more often than not vouched as a tumor suppressor. Histochemical analyses of clinical samples have shown PML to be downregulated in many cancer types such as that of breast, CNS, colon, prostate and Non-Hodgkin's Lymphoma ${ }^{2}$. These studies highlight an important role for PML in tumor suppression; however, the mechanisms underlying the loss of PML are largely unknown.

The largest part of studies on PML regulation is conducted at the post-translation level, SUMOylation, phosphorylation and ubiquitination being the chief contributors $^{3}$. On the contrary, much less is known about the transcriptional regulation of PML. The noted one is

\section{(c) The Author(s) 2019}

(c) Open Access This article is licensed under a Creative Commons Attribution 4.0 International License, which permits use, sharing, adaptation, distribution and reproduction cc) in any medium or format, as long as you give appropriate credit to the original author(s) and the source, provide a link to the Creative Commons license, and indicate if changes were made. The images or other third party material in this article are included in the article's Creative Commons license, unless indicated otherwise in a credit line to the material. If material is not included in the article's Creative Commons license and your intended use is not permitted by statutory regulation or exceeds the permitted use, you will need to obtain permission directly from the copyright holder. To view a copy of this license, visit http://creativecommons.org/licenses/by/4.0/. 


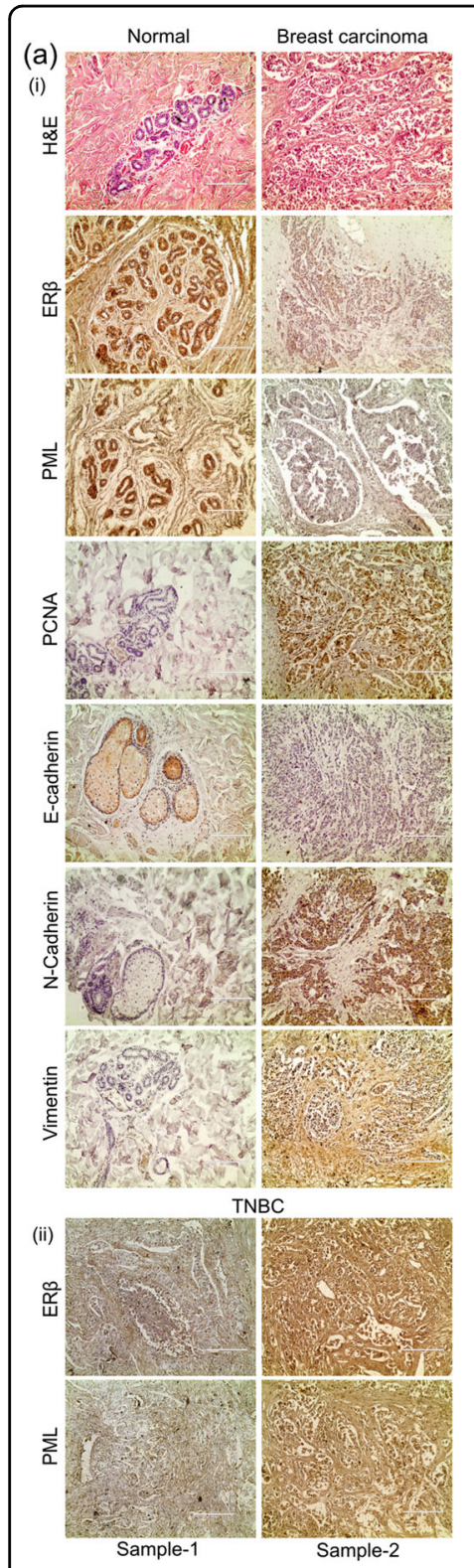

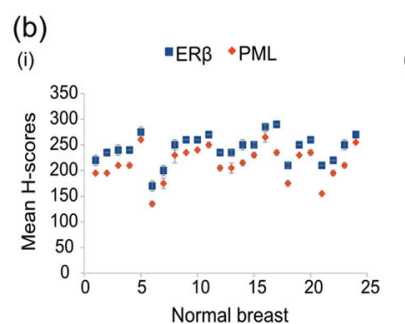

(c)

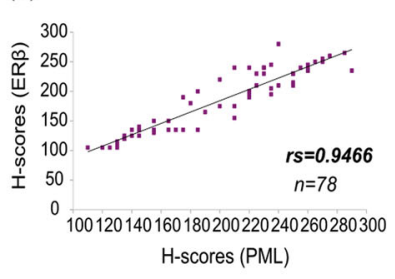

(d)
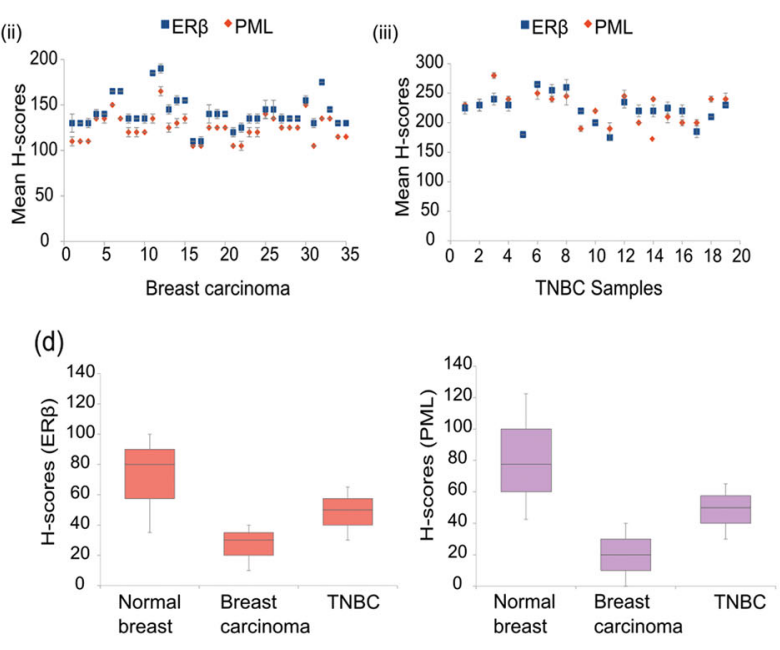

(iii) $\quad=\mathrm{ER} \beta \bullet \mathrm{PML}$

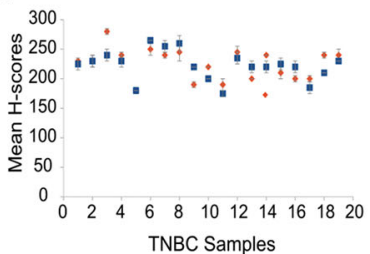

(f)
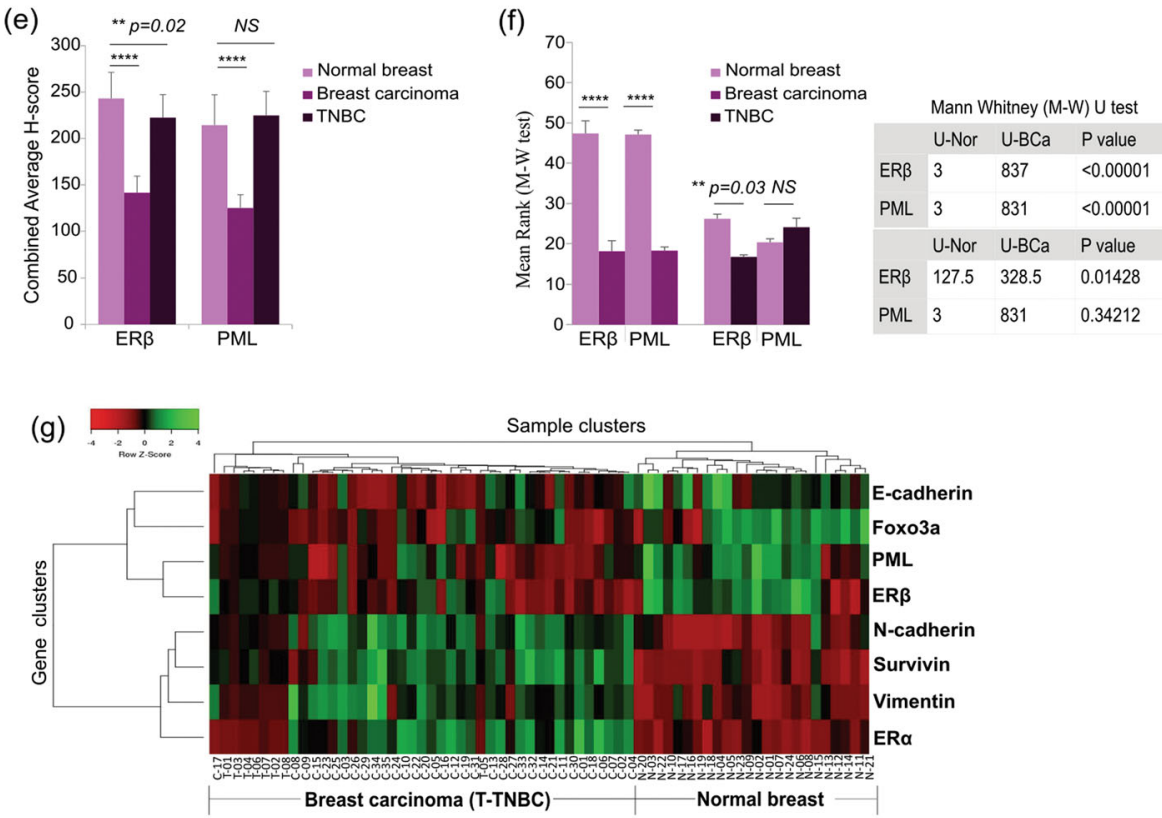

(h)
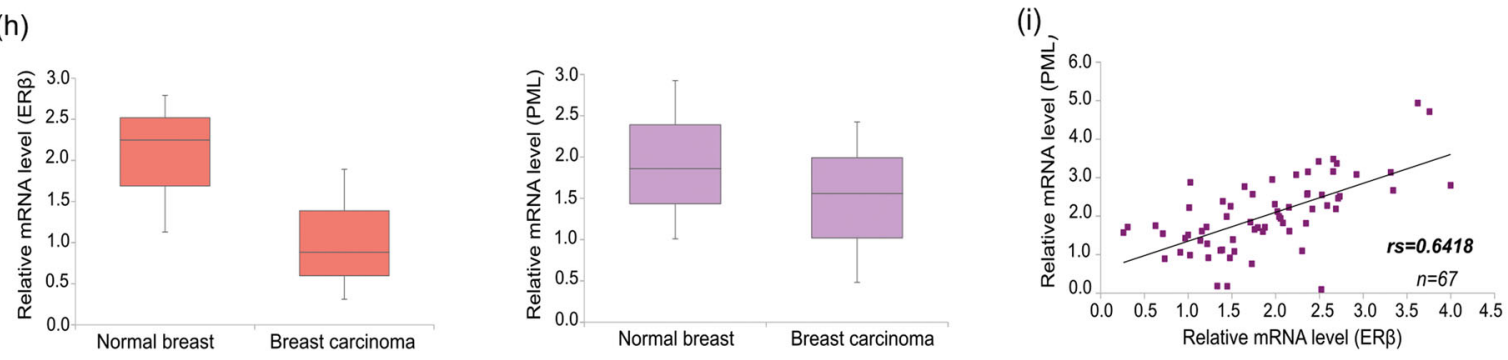

Fig. 1 (See legend on next page.) 
(see figure on previous page)

Fig. 1 Concomitant loss of ER $\beta$ and PML gene expression and both share a strong positive correlation in human breast tissue samples. a (i) Representative IHC images of the candidate proteins along with respective H\&E staining in human BCa and adjacent normal breast tissue samples and (ii) $I H C$ images of ERß and PML in two representative TNBC samples (Samples 1 and 2). All images are taken at $\times 200$ magnification. b Scatter-plot representation of the mean $\mathrm{H}$-scores of ERß and PML in (i) adjacent normal breast $(n=24)$, (ii) breast carcinoma $\left(\mathrm{ER}^{+}\right)(n=35)$ and (iii) TNBC ( $\left.n=19\right)$ tissues. $\mathbf{c}$ Depiction of correlation coefficient $\left(r_{s}\right)$ between mean $\mathrm{H}$-scores of ER $\beta$ and PML estimated from IHC images of both normal breast and BCa tissues combined. $\mathbf{d}$ Box-plots depicting distribution of H-scores of ERB and PML, in normal breast, BCa and TNBC samples. e Comparison of combined average $\mathrm{H}$-scores of ER $\beta$ and PML. $\mathbf{f}$ Graphical representation of mean ranks of the observed individual H-scores of ER $\beta$ and PML as obtained through calculations from M-W U-test (left). Table displaying the calculated Mann-Whitney U-test values for the H-scores of each observed protein is on the right. $\mathbf{g}$ Heat map of expression patterns of 8 genes from 24 normal $(\mathrm{N})$ and $43 \mathrm{BCa}$ (C) samples that includes 8 TNBC (T) samples, as obtained from qRT-PCR data (w.r.t GAPDH), displayed on a scale from green (low) to red (high). $\mathbf{h}$ Box-plots depicting relative gene expression of ERß and PML (w.r.t GAPDH) in normal breast and BCa samples. i Depiction of correlation coefficient ( $r_{s}$ ) between mean relative expressions of ER $\beta$ and PML genes as quantified from qRT-PCR data of both normal breast and BCa tissues combined. The error bars represent the mean ( \pm ) s.d. of independent two-tailed Student's t-tests, where $P<0.0001$ is represented as *** for highly significant

the interferon and TNFa induced transcriptional upregulation of PML mediated by STATs, which occupy the ISRE (induced by IFN $\alpha / \beta$ ) and GAS (IFN $\gamma$ activated) sites on PML promoter ${ }^{4-7}$. IL-6 also enhances PML transcription via NF-K $\beta$ and JAK/STAT pathway ${ }^{8}$. Activated Ras mediated transformation of MEFs also induces PML in a p53-dependent manner, ${ }^{9,10}$.

Breast cancer $(\mathrm{BCa})$ is the second most common cancer and the most common cancer among women in the world $^{11}$. Though mostly diagnosed based upon the presence or absence of three receptors: ER $\alpha, \mathrm{PR}$ and HER-2, $\sim 15-20 \%$ of all types of $\mathrm{BCa}$ in women do not express these receptors and, are, thus, defined as triple-negative $\mathrm{BCa}$ (TNBC) and are hence insensitive to hormone responsive treatments and frequently undergo local or systemic relapse ${ }^{12}$. Additionally, $30-40 \%$ of $\mathrm{ER}^{+}$patients receiving adjuvant tamoxifen therapy also eventually relapse $^{13,14}$. These indicate the need to identify new molecular signatures along with their prospective validation to derive novel therapeutic strategies.

One such factor could be ER $\beta$. Although present in smaller quantity as compared to ER $\alpha, E R \beta$ is found in about $70 \%$ of $\mathrm{BCa}^{15,16}$. As opposed to its alpha isoform, ER $\beta$ is known for its anti-proliferative actions ${ }^{17,18}$. ER $\beta 1$ positivity was associated with significantly better survival in patients with double-negative $\left(\mathrm{ER}^{-} / \mathrm{PR}^{-}\right)$or triple-negative tumors. Furthermore, ER $\beta$ expression in $E R \alpha^{+} / E R \beta^{+}$breast tumors is associated with a favorable response to adjuvant tamoxifen therapy ${ }^{19}$. The ratio between ER $\beta$ and ER $\alpha$ is high in normal glands, and decreases significantly in proliferative lesions ${ }^{20}$. This collected information directs to the possible role of ER $\beta$ in restoring the tumor suppression mechanism in BCa. In this study, we dissect the mechanisms underlying transcriptional regulation of PML in response to ER $\beta$. Upregulation of PML leads to decrease in downstream target Survivin along with increased stability of tumor suppressor Foxo3a, which in turn leads to upregulation of its transcriptional targets $\mathrm{p} 21$, and $\mathrm{p} 27$, thus leading to apoptosis and curbing oncogenesis.

\section{Results}

Concomitant loss of ER $\beta$ and PML in human breast cancer samples

To explore any possible connection between ER $\beta$ and PML in $\mathrm{BCa}$ we conducted immunohistochemical analyses in $\mathrm{BCa}(n=53)$ [including TNBC $(n=19)$ ] and adjacent normal tissue samples $(n=24)$. ER $\beta$ and PML show elevated expressions in normal tissues and a sharp decline in $\mathrm{BCa}$ samples. As expected, $\mathrm{N}$-cadherin, Vimentin and PCNA show enhanced expressions in carcinoma samples as opposite to E-cadherin which demonstrates a weakened expression (Fig. 1a (i), Fig. S1a). Interestingly, a subset of TNBC samples shows a heightened expression of ER $\beta$ along with PML, as opposed to the bulk of $\mathrm{ER}^{+}$BCa samples. However, the TNBC samples maintain an overall positive correlation between ER $\beta$ and PML (Fig. 1a (ii), Fig. S1b). Upon quantification by $\mathrm{H}$-scoring, both ER $\beta$ and PML depict significant differences in staining intensities between $\mathrm{BCa}$ and normal samples (Fig. 1b) and Spearman's rank correlation confirms that $\mathrm{H}$-scores of ER $\beta$ and PML bear a strong positive correlation $(r s=0.946)$ (Fig. 1c). Furthermore, the distribution and the difference between mean $\mathrm{H}$-scores of these proteins are statistically significant in $\mathrm{BCa}$ samples as compared to the normals, as also predicted by Mann-Whitney U-test (Fig. 1d, e, f).

qRT-PCR analyses conducted in the RNA isolated from the same set of tissue samples showed a unique grouping of ER $\beta$ and PML that shared the strongest correlation. Sample analyses too demonstrated a distinct clustering, with the normal and $\mathrm{BCa}$ samples on two ends of the spectrum (Fig. 1g). The distribution of ER $\beta$ and PML gene expression as calculated from normalized $\mathrm{Ct}$ values show a distinct difference between the $\mathrm{BCa}$ and normal tissue samples (Fig. 1h) and Spearman's rank analysis put a moderately strong positive correlation $(r s=0.642)$ between the two (Fig. 1i). Altogether, results indicate that ER $\beta$ and PML show a concomitant loss while maintaining positive correlation in human breast tissue samples. 


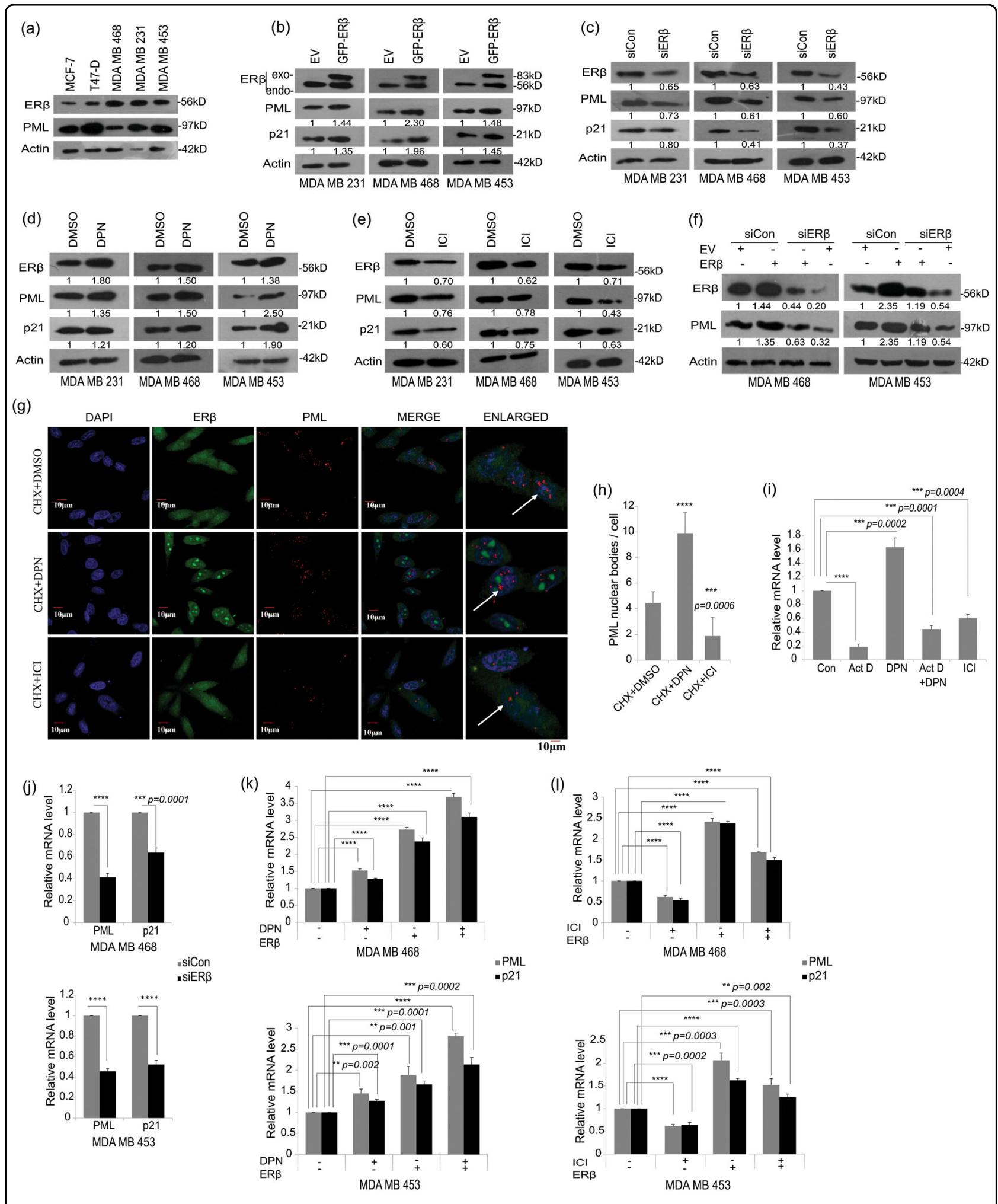

Fig. 2 (See legend on next page.) 
(see figure on previous page)

Fig. 2 ER $\beta$ positively regulates PML expression in breast cancer (BCa). a Immunoblot shows differential expression of ER $\beta$ and PML in multiple BCa cell lines. Three TNBC cell lines as depicted in the subsequent figures were used in this study. $\mathbf{b}$ Immunoblot analysis of cells transfected with either GFP-ERß or the empty vector and treated with DPN or DMSO and harvested at a total of $48 \mathrm{hr}$ post transfection. Densitometric analyses relative to loading control Actin are mentioned below the blots. p21 acts as positive control for ERß overexpression. $\mathbf{c}$ Immunoblot analysis of cells transfected with either scrambled siRNA or siRNA against ER $\beta$ and harvested $48 \mathrm{hr}$ post transfection. Immunoblot analysis of cells treated with $\mathbf{d}$ DPN $(10 \mathrm{nM})$ or $\mathbf{e} \mathrm{ICI}(1 \mu \mathrm{M})$ or DMSO $24 \mathrm{hr}$ post treatment. $\mathbf{f}$ Immunoblot analysis of cells transfected with either WT-ER $\beta$ or the empty vector, treated with DPN/DMSO and further transfected with either scrambled siRNA or siRNA against ERß. $\mathbf{g}$ Expression of ERß and PML in MDA MB 468 cells treated with either DPN or ICl or DMSO control in combination with $\mathrm{CHX}$, detected by immuno-cytochemistry. All images were taken at $\times 120$ maginification. Scale bars, $10 \mu \mathrm{m}$. All experiments were performed in triplicates, $n=3$. $\mathbf{h}$ Quantification of average number of PML nuclear bodies per MDA MB 468 cell treated with DPN or ICI in combination with CHX. PML-NBs were counted out of multiple randomly chosen fields from three biologically repeated experiments. i Relative mRNA expression (w.r.t $18 \mathrm{~s}$ rRNA) of PML assessed in MDA MB 468 cells treated with DPN or ICl, with actinomycin D (ActD) for $4 \mathrm{hr}$ either alone or prior to DPN treatment. $\mathbf{j}$ qRT-PCR analysis of cells transfected with either scrambled siRNA (siCon) or siRNA against ERß. $\mathbf{k}$ qRTPCR analysis of cells transfected with either GFP-ERß and/or treated with DPN. I qRT-PCR analysis of cells transfected with either empty vector or GFPERß along with or without ICI. The error bars represent the mean $( \pm)$ s.d. of independent two-tailed Student's $t$-tests, where $P<0.0001$ is represented as **** for highly significant

\section{$E R \beta$ regulates the expression level of PML protein in breast cancer cells}

To investigate the possible mechanistic interplay between PML and ER $\beta$ in $\mathrm{BCa}$, we checked the endogenous expression of $\mathrm{ER} \beta$ in multiple $\mathrm{BCa}$ cell lines. $\mathrm{A}$ prominent expression was seen in the three TNBC cell lines, which were hence used in further studies (Fig. 2a). To study the correlation in vitro, we overexpressed ER $\beta$ and activated it with ER $\beta$ specific ligand $D_{P N}{ }^{21,22}$. We observed an enhanced expression of PML upon ER $\beta$ activation in HEK293 as well as in multiple TNBC cell lines. p21 is a reported target gene of ER $\beta$ action $^{23}$ (Fig. 2b, Fig. S2a). On depleting endogenous ER $\beta$ we observed a sharp decline in PML expression (Fig. 2c). PML showed a sharp increase on treating the cells with DPN and plummeted on treatment with anti-estrogen $\mathrm{ICI}^{24-26}$ (Fig. $2 d$, e, Fig. S2b). In a combinatorial approach experiment, ER $\beta$ knockdown caused a decrease in PML expression, abolishing the effect of ER $\beta$ overexpression and its ligand dependent activation in TNBC cell lines (Fig. 2f). As observed from immuno-cytochemical studies, ER $\beta$ has a diffused presence all over the nucleus and cytoplasm, while interestingly, in the presence of agonist, it significantly accumulates in numerous nuclear foci. Simultaneously, DPN caused a visible increase in the number of PML-NBs that remain distributed throughout the nucleus whereas treatment with ICI shows a decline in their number (Fig. 2g, h). Taken together, we observe that ligand activated and/or overexpressed ER $\beta$ enhances PML expression.

\section{ER $\beta$ transcriptionally regulates PML gene expression in breast cancer cells}

For our mRNA studies we designed two qRT-PCR primer sets for PML spanning two different exon-exon junctions (Fig. S3a). Overexpression of ER $\beta$ led to significant upregulation of PML, as validated by both the primer sets (Fig. S3b). Set 1 is used for further studies as it would cover transcripts of each of the PML isoforms I-VI while Set 2 is specific only to PML-I mRNA. Actinomycin $\mathrm{D}$ caused a sharp fall in PML mRNA levels, similar to treatment with ICI and nullifies the effect of DPN (Fig. 2i). Since a combination of two siER $\beta$ oligonucleotides led to a better depletion of endogenous ER $\beta$ level in comparison to single siRNA's (Fig. S3c), this strategy is used for ER $\beta$ knockdown. ER $\beta$ depletion led to significant reduction in PML mRNA level (Fig. 2j). An increase in PML mRNA expression was observed on overexpressing ER $\beta$ alone or on treatment with DPN that augments further when ER $\beta$ overexpression is coupled with DPN treatment (Fig. 2k). Overexpression and activation of ER $\beta$ also leads to an increase in other pro-apoptotic factors and known targets of ER $\beta$ action, viz, p21, p27, Bim and Foxo3a (Fig. S3d, e). Conversely, treatment with ICI led to almost two-fold decrease in PML mRNA expression (Fig. 2l). These results imply that ER $\beta$ regulates both mRNA expression and protein level of PML in multiple TNBC cell lines.

\section{$E R \beta$ regulates PML promoter activity}

We cloned human and mouse PML promoters into pGL3 vector. Ligand independent ER $\beta$ overexpression led to an increase in human PML luciferase activity that augmented when treated with DPN (Fig. 3a, Fig. S4a). DPN can also directly activate two ER $\beta$ reporters: $3 \times$ ERE-TATA-luc and p21-luc in TNBC cell lines as opposed to HEK293, but more interestingly, ER $\beta$ unaided by a ligand is often able to surpass the sole response of DPN (Fig. S4c, d). Not surprisingly, ER $\beta$ when aided by a ligand has the highest response on both the reporters. We further generated an ER $\beta$ mutant construct $(\Delta 144-225)$ that lacks the ER $\beta$ DNA binding domain (DBD: amino acids 144-225) and introduced it or WT-ER $\beta$ in our overexpression system to study PML promoter activity (Fig. 3b). The luciferase activity of the mutant remained unchanged from its empty vector control, thus indicating that ER $\beta$ binding on PML promoter is direct (Fig. 3c). 


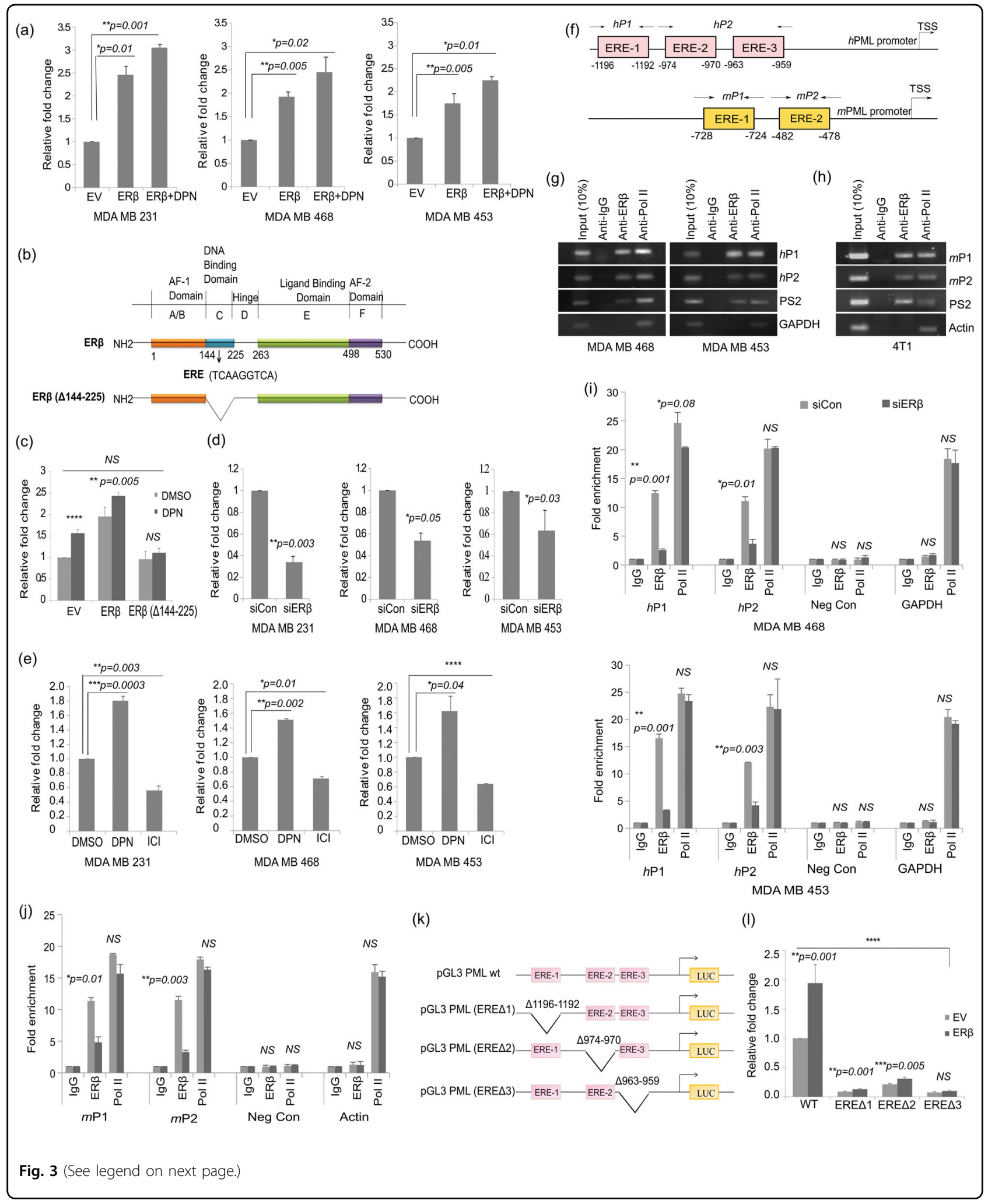


(see figure on previous page)

Fig. 3 ER $\beta$ regulates PML promoter activity. a Luciferase activity of PML promoter in cell lines co-transfected with WT-ERß, pGL3-PML-prom (human), and pRL-TK (Renilla luciferase construct), and treated with either DMSO or DPN. The figure represents relative fold change in luciferase readings, normalized against Renilla reporter activity. $\mathbf{b}$ Schematic representation of wild type ER $\beta$ gene mentioning all its domains and its mutant construct PCDNA ERß ( $\triangle 144-225)$, with its DNA binding domain (DBD) deleted. ERß DBD can occupy the ERE sites (consensus sequence TCAAGGTCA) on ERß target promoters. $\mathbf{c}$ Luciferase activity of PML promoter in MDA MB 468 cells transfected with either WT-ER $\beta$ or the mutant construct PCDNA ERß (144-225), along with pGL3-WT-PML-prom(human) and pRL-TK. $\mathbf{d}$ Luciferase activity of PML promoter co-transfected with either scrambled siRNA or siRNA against ERß, PGL3-PML-prom(human) and pRL-TK. e Luciferase activity of PML promoter co-transfected with pGL3-PML-prom(human) and pRL-TK and treated with DMSO, DPN or ICl. f Schematic representation of human $(-1447$ to +250$)$ and mouse $(-800$ to TSS) PML promoters containing ERE sites. Chromatin immunoprecipitation (ChIP) assay performed using the indicated antibodies in $\mathbf{g}$ human MDA MB 468 and MDA MB 453 and $\mathbf{h}$ mouse $4 \mathrm{~T} 1$ cells. RNA Polymerase II and IgG served as positive and negative controls respectively and PS2 promoter served as the control for ER $\beta$ binding. GAPDH and Actin promoters served as positive controls for Pol II in human and mouse ChIP assays respectively. ChIP assay performed on i MDA MB 468 and MDA MB 453 cells and j 4T1 cells transfected with either scrambled siRNA or with siRNA against ERß. 'Neg Con' stands for non-genomic intragenic regions serving as negative control for the same. $\mathbf{k}$ Schematic representation of the human WT PGL3 PML promoter and the three $\triangle E R E$ deletion constructs. I Luciferase activity measured in MDA MB 468 cells co-transfected with either WT ER $\beta$ along with PGL3-WT-PML-prom(human) or its deletion constructs and pRL-TK. Data are normalized to Renilla luciferase activity and represented as fold activity with respect to control cells. Error bars represent mean $( \pm)$ s.d. calculated from three independent experiments. $P<0.0001$ is represented as ***** for highly significant and NS denotes 'not significant'

Conversely, depletion of endogenous ER $\beta$ led to a decline in PML luciferase activity (Fig. 3d, Fig. S4b). This effect was further validated when DPN led to an increase in PML promoter activity and ICI caused a decline (Fig. 3e). Here too we observed a heightened response of unliganded ER $\beta$ as compared to DPN treatment on PML promoter activity. We establish so far that ER $\beta$ increases PML expression by transcriptional activation of its promoter.

\section{ER $\beta$ associates with chromatin and regulates PML promoter}

ER $\beta$ can transcriptionally regulate its target genes by either directly occupying Estrogen Response Element (ERE) sites on target promoters or indirectly by tethering to co-activators such as AP- $1^{27,28}$. As analyzed from Alggen PROMO and Eukaryotic Promoter database three half ERE sites and three AP-1 sites were observed upstream of TSS in human PML promoter $(-1447$ to $+250 \mathrm{bp}$ ). Two half ERE sites were observed in mouse PML promoter in a span of 800 bp upstream of TSS (Fig. 3f, Fig. S5a).

The chromatin immunoprecipitation (ChIP) data demonstrated that endogenous ER $\beta$, without any agonist treatment, binds to PML promoter in vivo by tethering to both ERE and AP-1 sites (Fig. 3g, h, Fig. S5b). Under ER $\beta$ knockdown conditions, ER $\beta$ occupancy of endogenous PML promoter was sharply reduced (Fig. 3i, j). To decipher the strength of binding at each of the ERE sites, we generated three deletion mutants (Fig. 3k). Luciferase activities of mutant PML promoters were significantly reduced, the effect being most prominent in ERE $\Delta 1$ and ERE $\Delta 3$. Also, the increase in PML promoter activity due to $E R \beta$ overexpression was abrogated in the case of ERE $\Delta 3$ (Fig. 3l). However a much less decrease in PML promoter activity was observed on deletion of AP-1 sites as compared to that of ERE sites, with maximum reduction seen in AP1 $\Delta 1$ (60\%) which is lesser than the minimum reduction observed in ERE $\Delta 2$ (80\%) (Fig. S5c). Furthermore there is a minimal but significant increase in PML promoter activity on exogenous ER $\beta$ overexpression in all the AP-1 deletion mutants, which is far less than that observed with WT-PML promoter. These findings allow us to remark that unliganded ER $\beta$ can directly interact with PML promoter, via its DBD, occupying the ERE and AP-1 sites. ER $\beta$ binding on ERE sites is more effective in transcriptional activation of the PML promoter as compared to the AP-1 sites.

\section{Foxo3a loss and Survivin gain in breast cancer samples is correlated to loss of ER $\beta$ and PML}

A previous work from our group had elucidated how stabilized PML acts as a scaffolding platform for activated Akt (pAKT) and its phosphatase (PHLPP2) inside the nucleus leading to de-phosphorylation and proteasomal degradation of Akt and hence stabilization of Foxo3a, in prostate cancer ${ }^{29}$. On the other hand PML is also known to induce apoptosis by down-regulation of Survivin, where it is seen that PML represses Survivin protein and mRNA expression in $\mathrm{MEFs}^{30}$. We speculated if these effects hold true in BCa. Gene expression analyses conducted on the same set of normal and $\mathrm{BCa}$ samples as used in Fig. 1, showed a higher expression of Survivin in BCa samples as opposed to that of Foxo3a which is abundantly overexpressed in normal breast samples (Fig. 4a). IHC analyses of BCa patient samples displayed a very low expression of Foxo3a, whereas pFoxo3a ${ }^{\mathrm{S} 253}$ (activated Akt phosphorylates Foxo3a at Ser-253 leading to its inactivation and degradation) showed distinct elevated staining. The reverse was observed in the normals. Survivin displayed marked elevation in $\mathrm{BCa}$ samples as compared to the normals (Fig. 4b, Fig. S1c). The box-plot 


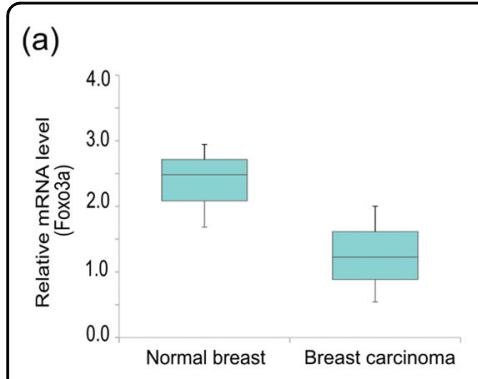

(c)
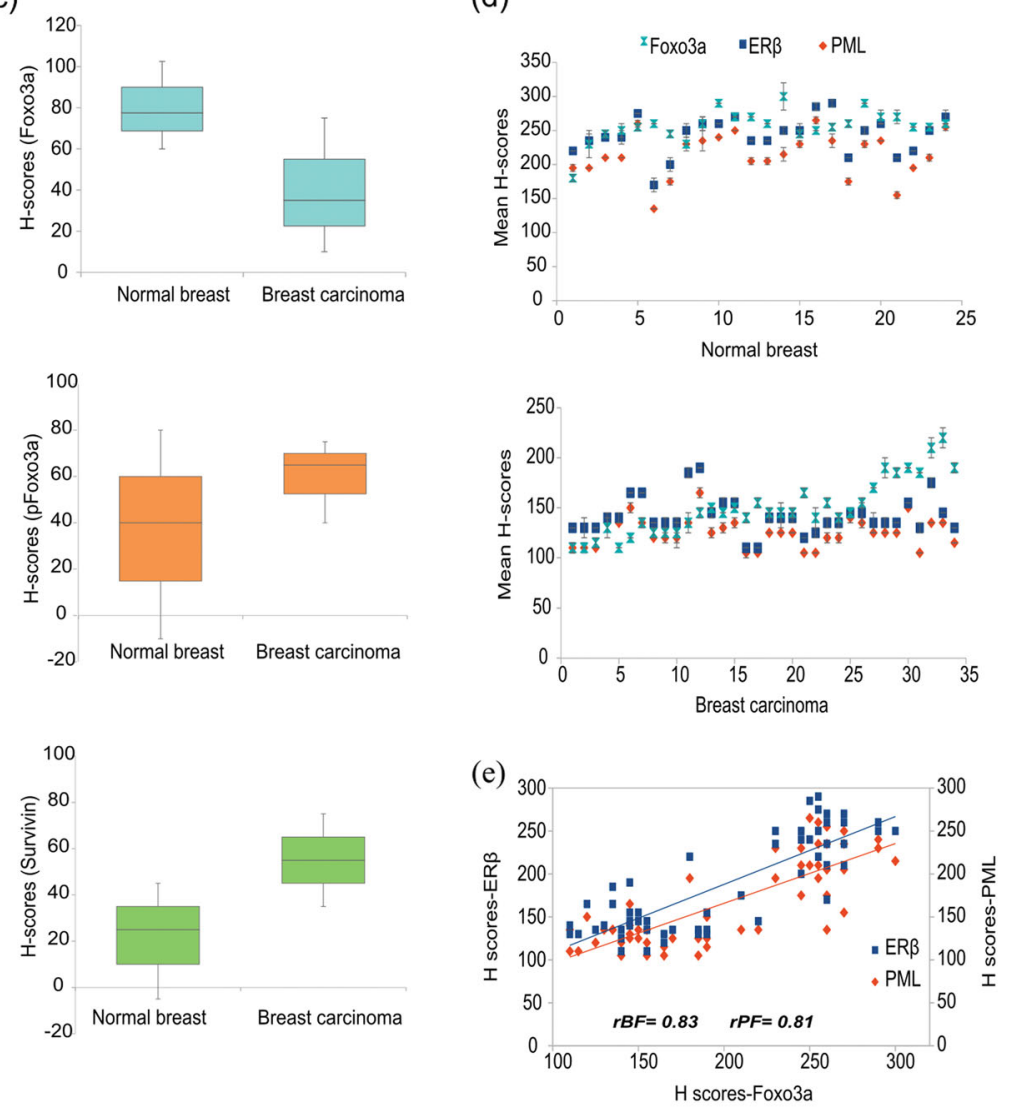

(h)
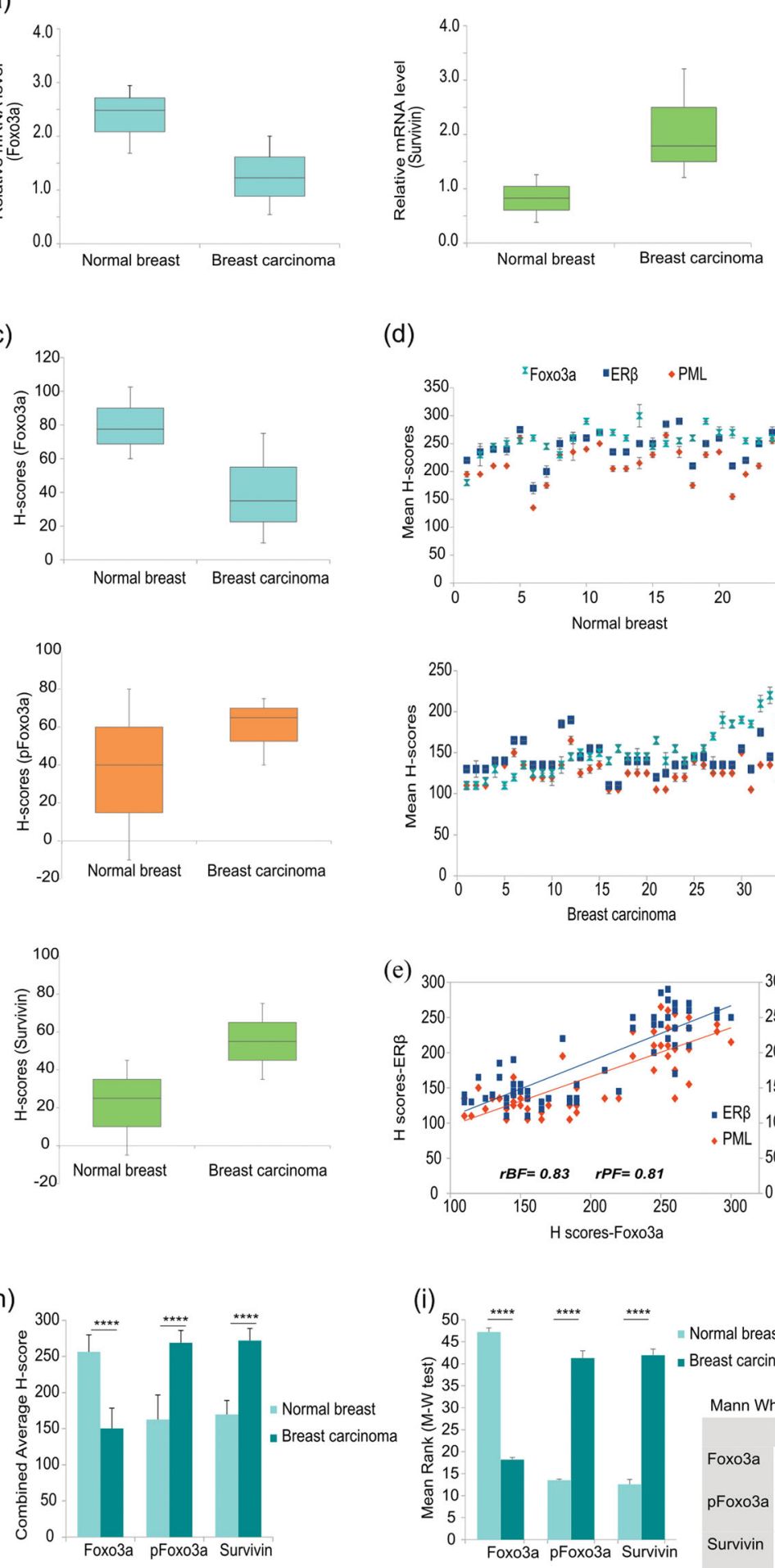

(d)
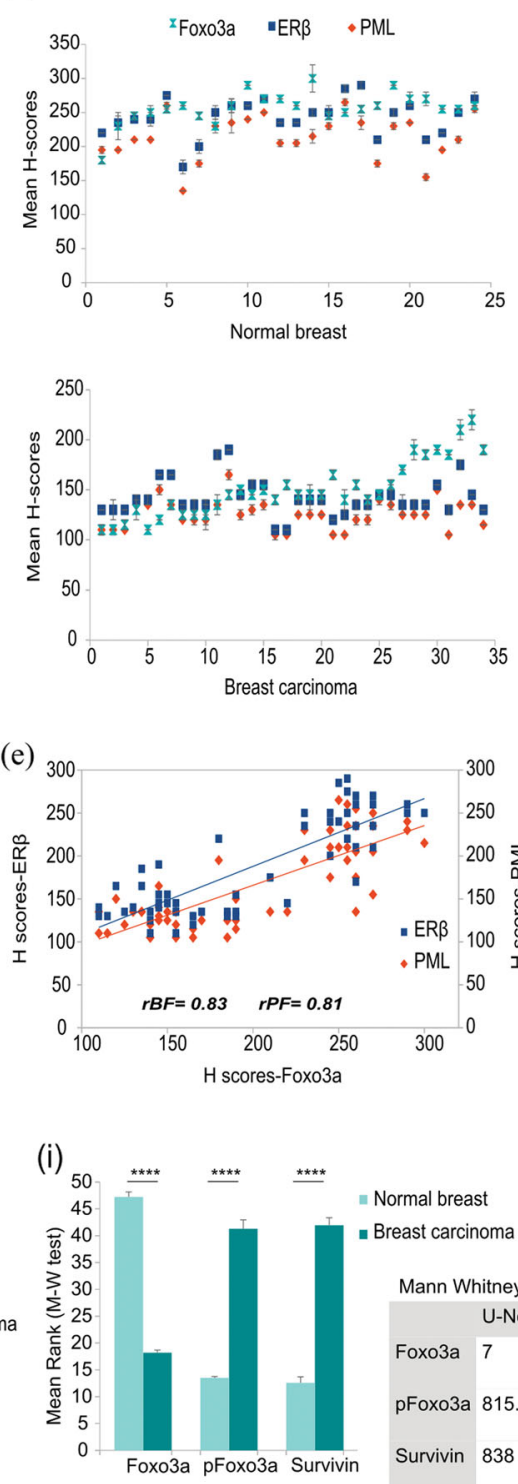

- Normal breast - Breast carcinoma

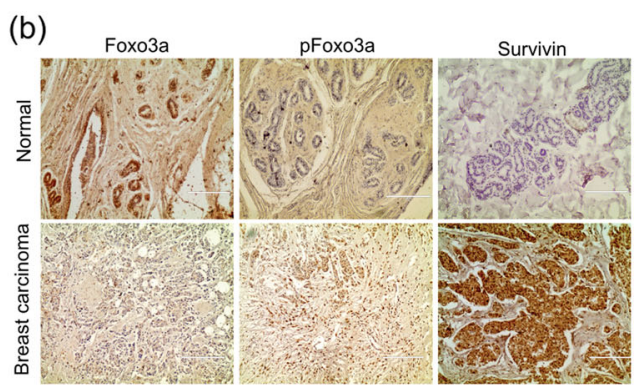

(f) $350 \quad=E R \beta$ - Survivin $\triangle \mathrm{pF}$ ×xo3a $+\mathrm{PML}$
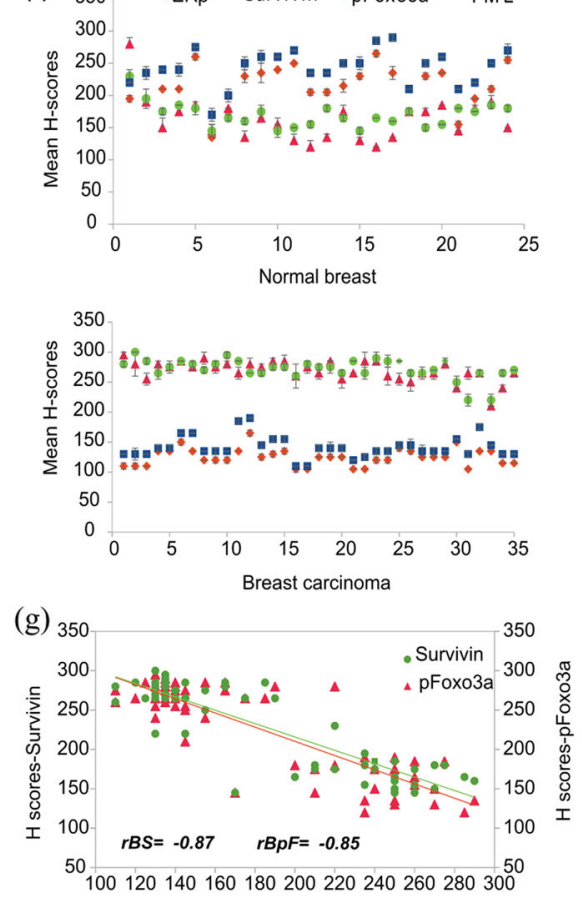
H scores-ERß

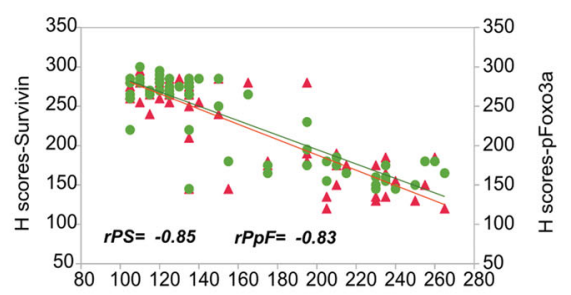

Mann Whitney (M-W) $U$ test statistics $\mathrm{U}$-Nor U-BCa $\mathrm{P}$ value

Foxo3a $7 \quad 833 \quad<0.00001$

pFoxo3a $815.5 \quad 24.5 \quad<0.00001$

Survivin $838 \quad 2 \quad<0.00001$

Fig. 4 (See legend on next page.) 


\begin{abstract}
(see figure on previous page)
Fig. 4 ER $\beta$ shares a positive correlation with Foxo3a and inversely correlates with Survivin in human breast cancer samples. a Box-plots depicting relative gene expression of FoxO3a and Survivin (w.r.t GAPDH) in the same set of normal breast and BCa samples, as used in Fig. 1. b Representative IHC images of the candidate proteins Foxo3a, pFoxo3a and Survivin of the human BCa and adjacent normal breast tissues (the same samples used in Fig. 1a). All images are taken at $\times 200$ magnification. $\mathbf{c}$ Box-plots depicting distribution of $\mathrm{H}$-scores of Foxo3a, pFoxo3a and Survivin, in normal breast $(n=24)$ and BCa $(n=35)$ samples. Scatter-plot representation of the mean H-scores of $\mathbf{d}$ ERß, PML and FoxO3a and $\mathbf{f} E R \beta$, PML, pFoxo3a and Survivin in adjacent normal breast and BCa tissues. Depiction of correlation coefficient ( $r s$ ) between mean H-scores of e ERß-Foxo3aPML (g) Survivin-ERß-pFoxo3a (top) and Survivin-PML-pFoxo3a (bottom) estimated from IHC images of both normal breast and BCa tissues combined. $\mathbf{h}$ Comparison of combined average H-scores of Foxo3a, pFoxo3a and Survivin. $\mathbf{i}$ Graphical representation of mean ranks of the observed individual $\mathrm{H}$-scores of Foxo3a, pFoxo3a and Survivin as obtained through calculations from M-W U-test (left). Table displaying the calculated Mann-Whitney U-test values for the $\mathrm{H}$-scores of each observed protein is on the right. The error bars represent the mean $( \pm)$ s.d. of independent twotailed Student's $t$-tests. $P<0.0001$ is represented as ${ }^{* * *}$ for highly significant
\end{abstract}

distribution (Fig. 4c) and H-score analysis (Fig. 4d) proved that ER $\beta$, PML and Foxo3a share a similar trend in both $\mathrm{BCa}$, as well as in normal samples, whereas ER $\beta$ and PML share an opposing trend with pFoxo3a ${ }^{\mathrm{S} 53}$ and Survivin (Fig. 4f). Spearman's Correlation drawn on H-scores, showed that ER $\beta$ and PML share a strong positive correlation with Foxo3a $\left(r_{s}=0.83\right.$ and 0.81 , respectively) (Fig. 4e). A strong negative correlation exists between ER $\beta$-Survivin $\left(r_{s}=-0.87\right)$, ER $\beta$-pFoxo3a ${ }^{\mathrm{S} 253}\left(r_{s}=-0.85\right)$, PML-Survivin $\left(r_{s}=-0.85\right)$ and PML-pFoxo3a ${ }^{\mathrm{S} 253}\left(r_{s}=\right.$ -0.83 ) (Fig. 4g). The combined average H-scores (Fig. 4h) and the difference in the H-scores of Foxo3a, pFoxo3a ${ }^{\text {s253 }}$ and Survivin between normal and the BCa samples was also statistically significant as analyzed by Mann-Whitney U-test (Fig. 4i). The expression of "ER $\beta$-PML-(Foxo3a/ Survivin)" signaling pathway components has been summarized in Tables 1 and 2. From these results we deduced that ER $\beta$-PML signalling might give a stronghold on the expression of Foxo3a and Survivin in BCa.

\section{Downregulation of Foxo3a and upregulation of Survivin is the result of ER $\beta-P M L$ signaling}

We proceeded to assess the role of ER $\beta$-PML signaling on Foxo3a and Survivin. Activated ER $\beta$ led to a rise in PML expression from its depleted state under its knocked-down condition. A rescue in PML expression saw a simultaneous rise in Foxo3a with a concomitant decline of pFoxo3a $\mathrm{a}^{\mathrm{S} 253}$ and Survivin (Fig. 5a). Furthermore, we depleted already overexpressed and activated ER $\beta$, and observed an initial rise of PML and Foxo3a that reduced under ER $\beta$ knockdown conditions. Conversely, pFoxo3a ${ }^{\mathrm{S} 253}$ and Survivin followed an opposite pattern (Fig. 5b). DPN caused an increase in Foxo3a and other pro-apoptotic factors, Bim, Bax and cleaved Caspase 3 along with a reduction in pFoxo3a ${ }^{\mathrm{S} 253}$ and Survivin. The converse results were observed under the treatment with ICI (Fig. 5c). These results were further confirmed by conducting a dose dependant overexpression of ER $\beta$ aided by ligand binding (Fig. 5d). Additionally, we also see a dose dependent increase in PARP, a notable marker of cellular apoptosis, on ER $\beta$ overexpression coupled with increasing doses of DPN (Fig. 5e). The observation at the protein level was faithfully imitated at the transcript level, where ER $\beta$ overexpression intensified the expression of Foxo3a and reduced that of Survivin (Fig. 5f). The opposite effect was observed on depletion of endogenous ER $\beta$ (Fig. 5g). We were curious to understand whether ER $\beta$ mediated down regulation of Survivin was indeed an effect of PML trans-repression. Confirming our hypotheses, inhibition of PML expression was associated with a significant increase in Survivin expression which depleted on the introduction of ER $\beta$ (Fig. 5h). If Foxo3a is a bona fide target of ER $\beta$-PML signaling network, the regulator molecules should have a role on the transcriptional activity of Foxo3a. To confirm this, we conducted qRTPCR studies where overexpression of either ER $\beta$ or PML led to an increase in mRNA expression of Foxo3a target genes- p21, p27, and Bim (Fig. 5i). This result is analogous to individual overexpression of Foxo3a itself, where an expected rise in their mRNA expression gets further augmented when the cells were co-transfected with either ER $\beta$ or PML. Conversely, knockdown of ER $\beta$ and PML leads to a reduction in the gene expression of the Foxo3a target genes (Fig. 5j). Luciferase assays showed that both ER $\beta$ and PML upregulated p21 and p27 promoter transactivation and further augmented the results observed under Foxo3a overexpression (Fig. 5k). Noticeably, upon knockdown of either ER $\beta$ or PML, reporter activity of both the promoters declined (Fig. 5l). All these results put together explained that ER $\beta$ 's regulation of PML gene is required for the downregulation of anti-apoptotic factor Survivin and increase in the expression and transcriptional activity of tumor suppressor Foxo3a.

\section{ER $\beta$-PML network causes reduced cell proliferation and migration}

$\mathrm{ER} \beta$ is known to cause a reduced proliferation of TNBC cell lines. Hence, we investigated the effect of 'ER $\beta$-PML(Foxo3a/Survivin)' network on cellular proliferation. A reduction in anchorage dependent growth was observed 
Table 1 Correlation coefficients between immuno-histochemistry scores of the ERß-PML-(Foxo3a/Survivin) signaling pathway components in normal human breast and breast cancer tissues

\begin{tabular}{|c|c|c|c|c|c|c|c|c|c|c|c|c|c|c|}
\hline & & & \multicolumn{3}{|l|}{ PML } & \multicolumn{3}{|c|}{ Foxo3a } & \multicolumn{3}{|c|}{ pFoxo3a } & \multicolumn{3}{|l|}{ Survivin } \\
\hline & & & $\mathbf{T}$ & $\mathbf{N}$ & $\mathrm{BCa}$ & $T$ & $\mathbf{N}$ & $\mathrm{BCa}$ & $\mathrm{T}$ & $\mathbf{N}$ & $\mathrm{BCa}$ & $\mathrm{T}$ & $\mathrm{N}$ & $\mathrm{BCa}$ \\
\hline \multirow[t]{6}{*}{ ERß } & T & $r_{s}$ & 0.980 & & & 0.839 & & & -0.853 & & & 0.874 & & \\
\hline & & P & 0.029 & & & 0.002 & & & $* * * *$ & & & $* * * *$ & & \\
\hline & $\mathrm{N}$ & $r_{s}$ & & 0.948 & & & 0.787 & & & -0.546 & & & -0.537 & \\
\hline & & P & & 0.002 & & & 0.001 & & & $* * * *$ & & & $* * * *$ & \\
\hline & $\mathrm{BCa}$ & $r_{s}$ & & & 0.844 & & & 0.884 & & & -0.697 & & & -0.722 \\
\hline & & $P$ & & & $* * * *$ & & & 0.031 & & & $* * * *$ & & & $* * * *$ \\
\hline \multirow[t]{6}{*}{ PML } & T & $r_{s}$ & & & & 0.815 & & & -0.835 & & & -0.856 & & \\
\hline & & P & & & & 0.002 & & & 0.015 & & & 0.004 & & \\
\hline & $\mathrm{N}$ & $r_{s}$ & & & & & 0.744 & & & -0.720 & & & -0.709 & \\
\hline & & $P$ & & & & & 0.035 & & & 0.039 & & & 0.022 & \\
\hline & $\mathrm{BCa}$ & $r_{s}$ & & & & & & 0.414 & & & 0.320 & & & 0.860 \\
\hline & & $P$ & & & & & & 0.132 & & & 0.210 & & & 0.001 \\
\hline \multirow[t]{6}{*}{ Foxo3a } & T & $r_{s}$ & & & & & & & -0.903 & & & -0.938 & & \\
\hline & & P & & & & & & & 0.003 & & & $* * * *$ & & \\
\hline & $N$ & $r_{s}$ & & & & & & & & -0.486 & & & -0.676 & \\
\hline & & P & & & & & & & & $* * * *$ & & & $* * * *$ & \\
\hline & $\mathrm{BCa}$ & $r_{s}$ & & & & & & & & & -0.600 & & & -0.613 \\
\hline & & P & & & & & & & & & $* * * *$ & & & $* * * *$ \\
\hline
\end{tabular}

T-Total samples, N-Normal human breast samples $(n=24)$, BCa-Human breast cancer samples $(n=35)$. $r_{s^{-}}$Pearson's Correlation Coefficient, $P$ - Student's $t$-Test, significant at $P<0.05$

when cells were treated with DPN as compared to the controls, in colony formation assay (Fig. 6a). The number and the size of colonies formed significantly reduced on DPN treatment. Wound healing assay shows a similar reduction in cellular migration when treated with DPN (Fig. 6b). Cell viability as analyzed from MTT assay is also seen to decrease with an increase in DPN dose where a nominal dose $(10 \mathrm{nM})$ of DPN shows significant reduction in cell viability (Fig. 6c). This effect of ER $\beta$ induction was reversed by PML knockdown, as we observed a significant rise in cell survival, as a mark of increased cellular proliferation in siPML transfected cells. DPN stimulation reduced cell survival by $30 \%$ in siCon cells but by a lesser proportion ( 14\%) in siPML cells (Fig. 6d). We further see an increase in Caspase 3/7 activity in the presence of DPN (Fig. 6e), whereas, PML depletion is associated with a reduction in Caspase activity which is rescued upon DPN stimulation (Fig. 6f). Overexpression of ER $\beta$ also disturbs the cell-cycle progression as is observed from the increase in the percentage of cells in the Sub- $G_{0}$ and $G_{0}$ stages while a reduction is observed in the G2/M phase. This growth suppressive effect of ER $\beta$ is reversed under conditions of PML knockdown, when percentage of cells in the G2/M increases with a drop in the proportion of apoptotic cells (Fig. 6g). The reverse phenomenon is observed when PML depletion causes a rise in the proliferative cells, as also indicated from the viability assay results. Induction of ER $\beta$ under these conditions shifts the cell cycle towards apoptosis as observed from a rise in sub- $\mathrm{G}_{0}$ population with a concomitant decrease in $\mathrm{G} 2 / \mathrm{M}$ phase (Fig. 6h). These results indicate that ER $\beta$ promotes growth suppression via apoptosis and these effects are abrogated on PML induction. Thus ER $\beta$ induction is important for enhanced expression of PML, leading to activation of tumor suppressors Foxo3a, p21 and caspases, reduction of pro-oncogenic molecule Survivin, and subsequent effect on apoptosis and tumor suppression.

\section{Discussion}

Several lines of research and evidences have elucidated the role of PML in tumor suppression and its concomitant loss in multiple cancers ${ }^{2,29}$. PML expression is reduced or abolished in $21 \%$ and $31 \%$ of breast carcinomas, respectively, where loss of PML correlates with bad prognosis 
Table 2 Summary of the corresponding immune-histochemistry expression of ERß-PML-(Foxo3a/Survivin) signaling pathway components in human normal breast $(n=24)$ and breast cancer tissues $(n=35)$

\begin{tabular}{|c|c|c|c|c|c|c|c|c|c|c|c|}
\hline & & & & Normal & Foxo3a-Low & $\begin{array}{l}\text { Foxo3a- } \\
\text { High }\end{array}$ & Total & Normal & Foxo3a-Low & $\begin{array}{l}\text { Foxo3a- } \\
\text { High }\end{array}$ & Total \\
\hline & & & & PML-Low & 0 & 0 & 0 & ER $\beta$-Low & 0 & 0 & 0 \\
\hline & & & & PML-High & 1 & 23 & 24 & ER $\beta$-High & 0 & 24 & 24 \\
\hline & & & & Total & 1 & 23 & 24 & Total & 0 & 24 & 24 \\
\hline Normal & $\begin{array}{l}\text { PML- } \\
\text { Low }\end{array}$ & $\begin{array}{l}\text { PML- } \\
\text { High }\end{array}$ & Total & & & & & & & & \\
\hline ER $\beta$-Low & 0 & 0 & 0 & $\begin{array}{l}\text { Breast } \\
\text { Cancer }\end{array}$ & Foxo3a-Low & $\begin{array}{l}\text { Foxo3a- } \\
\text { High }\end{array}$ & Total & $\begin{array}{l}\text { Breast } \\
\text { Cancer }\end{array}$ & Foxo3a-Low & $\begin{array}{l}\text { Foxo3a- } \\
\text { High }\end{array}$ & Total \\
\hline ERß-High & 1 & 23 & 24 & PML-Low & 21 & 1 & 27 & ERß-Low & 16 & 11 & 27 \\
\hline \multirow[t]{2}{*}{ Total } & 1 & 23 & 24 & PML-High & 13 & 0 & 8 & ER $\beta$-High & 6 & 2 & 8 \\
\hline & & & & Total & 34 & 1 & 35 & Total & 22 & 13 & 35 \\
\hline $\begin{array}{l}\text { Breast } \\
\text { Cancer }\end{array}$ & $\begin{array}{l}\text { PML- } \\
\text { Low }\end{array}$ & $\begin{array}{l}\text { PML- } \\
\text { High }\end{array}$ & Total & Normal & $\begin{array}{l}\text { Survivin- } \\
\text { Low }\end{array}$ & $\begin{array}{l}\text { Survivin- } \\
\text { High }\end{array}$ & Total & Normal & $\begin{array}{l}\text { Survivin- } \\
\text { Low }\end{array}$ & $\begin{array}{l}\text { Survivin- } \\
\text { High }\end{array}$ & Total \\
\hline ER $\beta$-Low & 27 & 0 & 27 & PML-Low & 1 & 4 & 5 & ER $\beta$-Low & 0 & 0 & 0 \\
\hline ERß-High & 7 & 1 & 8 & PML-High & 0 & 19 & 19 & ERß-High & 5 & 19 & 24 \\
\hline \multirow[t]{5}{*}{ Total } & 34 & 1 & 35 & Total & 1 & 23 & 24 & Total & 5 & 19 & 24 \\
\hline & & & & $\begin{array}{l}\text { Breast } \\
\text { Cancer }\end{array}$ & $\begin{array}{l}\text { Survivin- } \\
\text { Low }\end{array}$ & $\begin{array}{l}\text { Survivin- } \\
\text { High }\end{array}$ & Total & $\begin{array}{l}\text { Breast } \\
\text { Cancer }\end{array}$ & $\begin{array}{l}\text { Survivin- } \\
\text { Low }\end{array}$ & $\begin{array}{l}\text { Survivin- } \\
\text { High }\end{array}$ & Total \\
\hline & & & & PML-Low & 0 & 0 & 27 & ER $\beta$-Low & 0 & 27 & 27 \\
\hline & & & & PML-High & 34 & 1 & 8 & ER $\beta$-High & 0 & 8 & 8 \\
\hline & & & & Total & 34 & 1 & 35 & Total & 0 & 35 & 35 \\
\hline
\end{tabular}

IHC expression in the range $0-150$ is considered as Low and that between 151 and 300 is considered as High

and increased tumor grade ${ }^{2}$. Putting this literature into our perspective we sought out to understand how PML gene is regulated in breast cancer. A previous work from our group had established the role of ER $\alpha$ in reducing PML protein expression in BCa cells, via upregulation of $\mathrm{CK} 2 \alpha^{31}$, of which PML is a notable downstream target ${ }^{32}$. It was our interest to understand how PML expression can be regulated in the absence of ER $\alpha$ and thus be stabilized in $\mathrm{BCa}$ cells to bring down oncogenesis. We focussed on ER $\beta$ which is gaining prominence for its role in inhibiting the growth and invasiveness of BCa cells.

$\mathrm{ER} \beta$ is a transcriptional regulator whereby it up-regulates various tumor suppressors such as p53, p21, and down regulates prominent pro-oncogenic and cell cycle progression factors viz., Cyclin D1, cMyc, Hif1 $\alpha$, VEGF, FOXM1 etc $^{33-37}$. We observed that both ER $\beta$ and PML maintain a strong positive correlation in human $\mathrm{BCa}$ and adjacent normal tissues, with a strong expression in normal tissues that declines in $\mathrm{BCa}$ samples. In this context, the possible role of ER $\beta$ in regulating PML expression can be studied (Fig. 7a).We observed that ER $\beta$ enhances PML mRNA and protein levels in multiple TNBC cell lines. We note that
ER $\beta$ gets re-localized in discrete nuclear foci once being treated by DPN. Certain previous reports had mentioned the nucleolar localization of ER $\alpha$ and had hypothesized that this might be associated with hormonal induction of preribosomal RNA synthesis ${ }^{38}$ and/or with the promoter of target genes, thus turning them $\mathrm{on}^{39}$. This phenomenon of ER $\beta$ localization in nucleoli of MDA MB 468 cells is a novel finding and raises pertinent questions regarding its role. Another interesting observation was that unliganded ER $\beta$ alone, was able to elicit the regulation of PML, which gets augmented in the presence of DPN. Our luciferase assay results proved our case stronger, where we observed ER $\beta$ mediated activation of PML promoter. This is in line with previous reports where unliganded ER $\beta$ is capable of interacting with target gene promoters and elicit changes in gene expression ${ }^{40-44}$. It reiterates the thought that transcriptional activity of ER $\beta$ is highly cell and promoter dependent and that activity of N-terminal AF-1 might be modulated by several other signaling cascades ${ }^{45,46}$. Here, we are the first to establish and report the presence and the role of ERE and AP-1 sites on PML promoter. ChIP studies indicated a strong binding of ER $\beta$ on the PML promoter. 


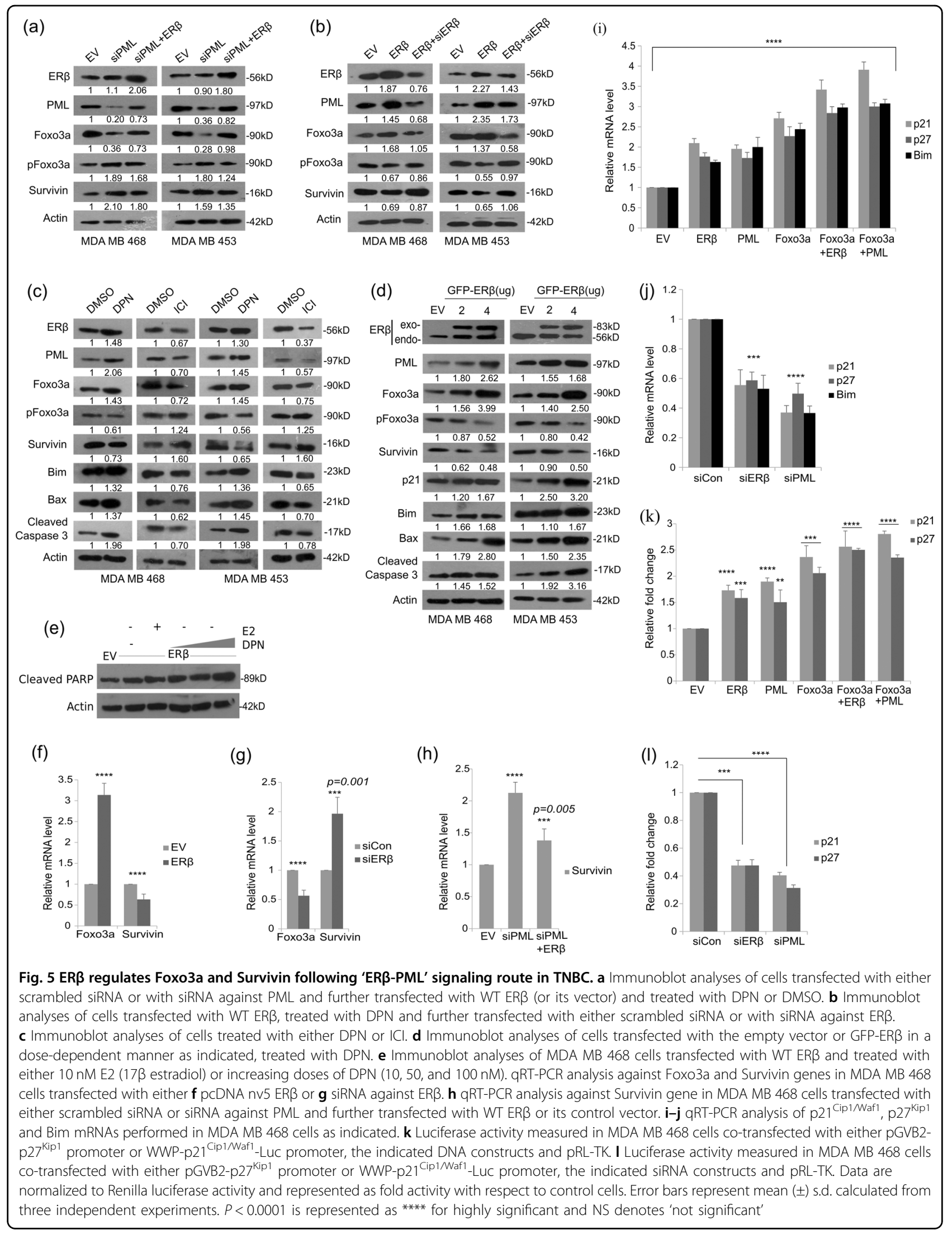


(a)
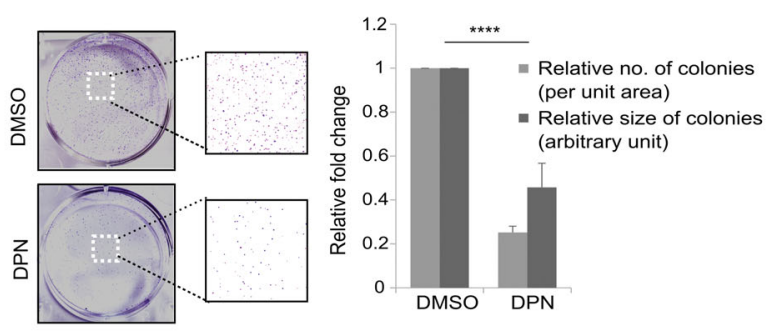

(c)

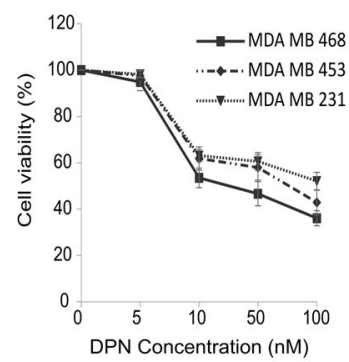

(g)

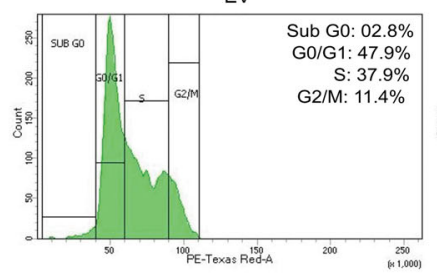

(d)

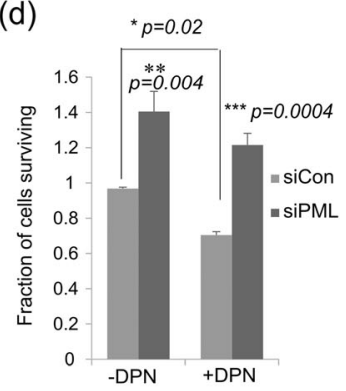

(b)
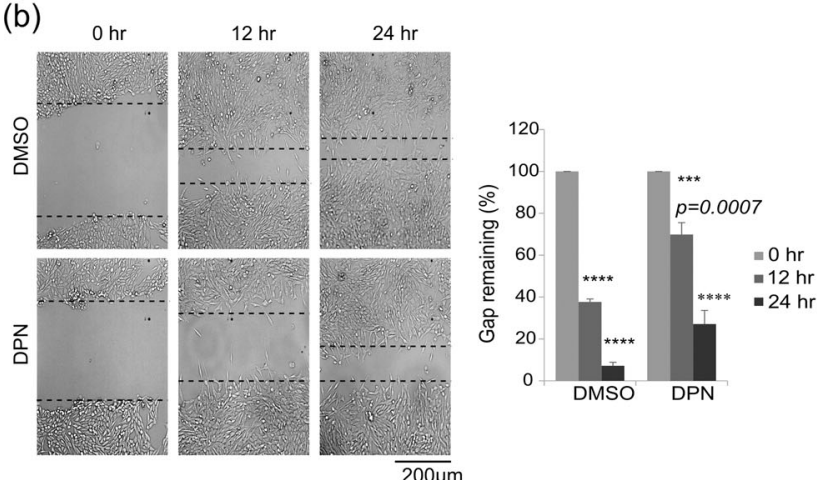

(e)

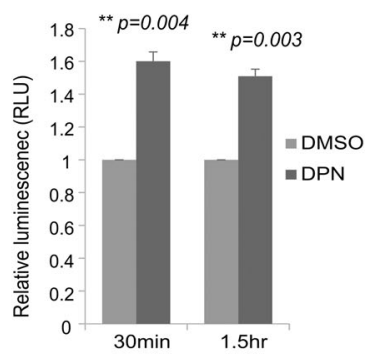

(f)

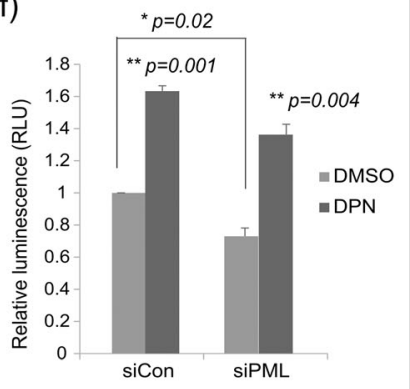

(h)

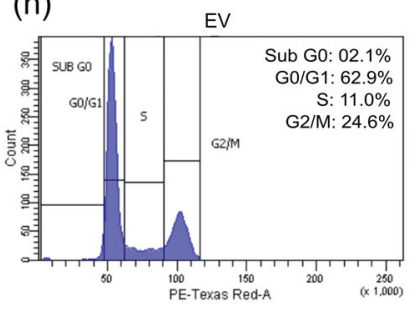

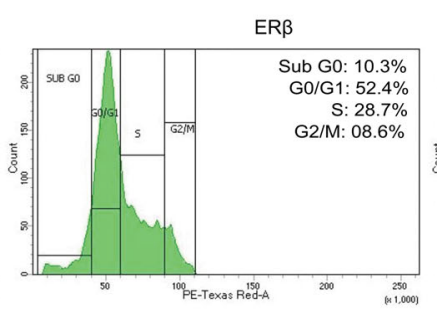

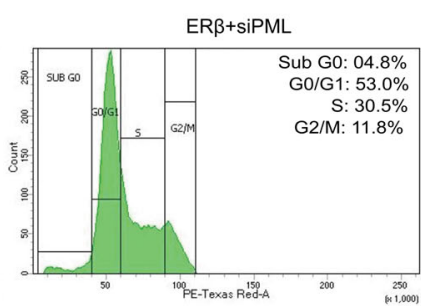

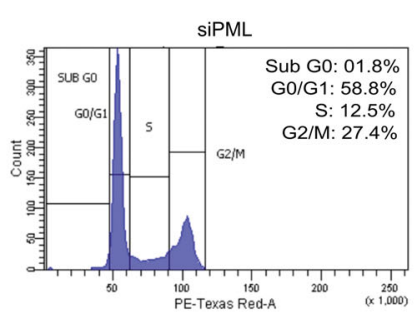
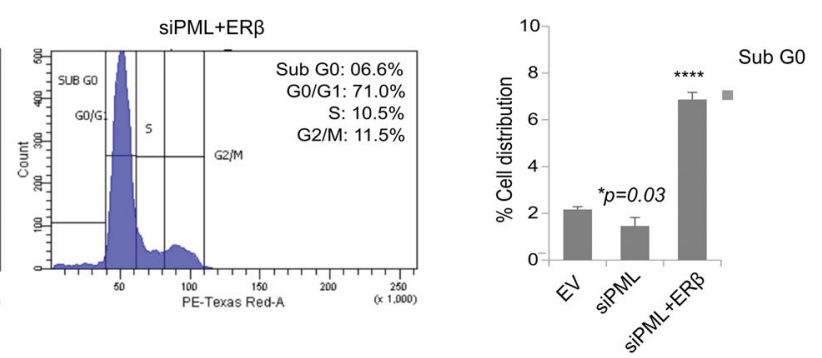

Fig. 6 ER $\beta$ induction results in decrease in cellular proliferation and migration. a Cell proliferation assay measured in MDA MB 468 cells treated with either $10 \mathrm{nM}$ DPN or DMSO kept for 15 days and as observed from colony formation capacity $(n=3)$. The size and number of colonies are represented in the bar diagram. $\mathbf{b}$ Scratch assay performed on MDA MB 468 cells subjected to DPN or DMSO and at the indicated time slots for a total period of $24 \mathrm{hr}$. Scale bar of $1000 \mu \mathrm{m}$ applies to all the images. Percentage of the gap remaining measured is represented as bar diagram. c Cell viability as determined by MTT Assay in multiple TNBC cell lines treated with increasing concentration of DPN for $48 \mathrm{hr}$. $\mathbf{d}$ MDA MB 468 cells transfected with siCon or siPML and treated with or without $10 \mathrm{nM}$ DPN and cell viability determined by MTT assay as percentage of untransfected cells at the end of $72 \mathrm{hr}$. e Caspase3/7 activity measured in MDA MB 468 cells treated with DPN or DMSO as an increase in luminescence, either 30 min or $1.5 \mathrm{hr}$ post addition of the reagent (mean of three separate experiments and \pm s.e.m. calculated using Student's $t$-test). $\mathbf{f}$ MDA MB 468 cells transfected with siCon or siPML and treated with or without DPN and Caspase3/7 activity measured 30 min post addition of the reagent (mean of three separate experiments, \pm s.e.m. calculated using Student's $t$-test). $\mathbf{g}$ Cell cycle distribution measured by flow cytometry in MDA MB 468 cells transfected with exogenous WT$E R B$ and further transfected with either scrambled siRNA or with siRNA against PML. $\mathbf{h}$ Cell cycle distribution measured by flow cytometry in MDA MB 468 cells transfected with either scrambled siRNA or with siRNA against PML and further transfected with WT-ERß. Error bars represent mean ( \pm ) s.d. calculated from three independent experiments. $P<0.0001$ is represented as ${ }^{* * *}$ for highly significant and NS denotes 'not significant' 


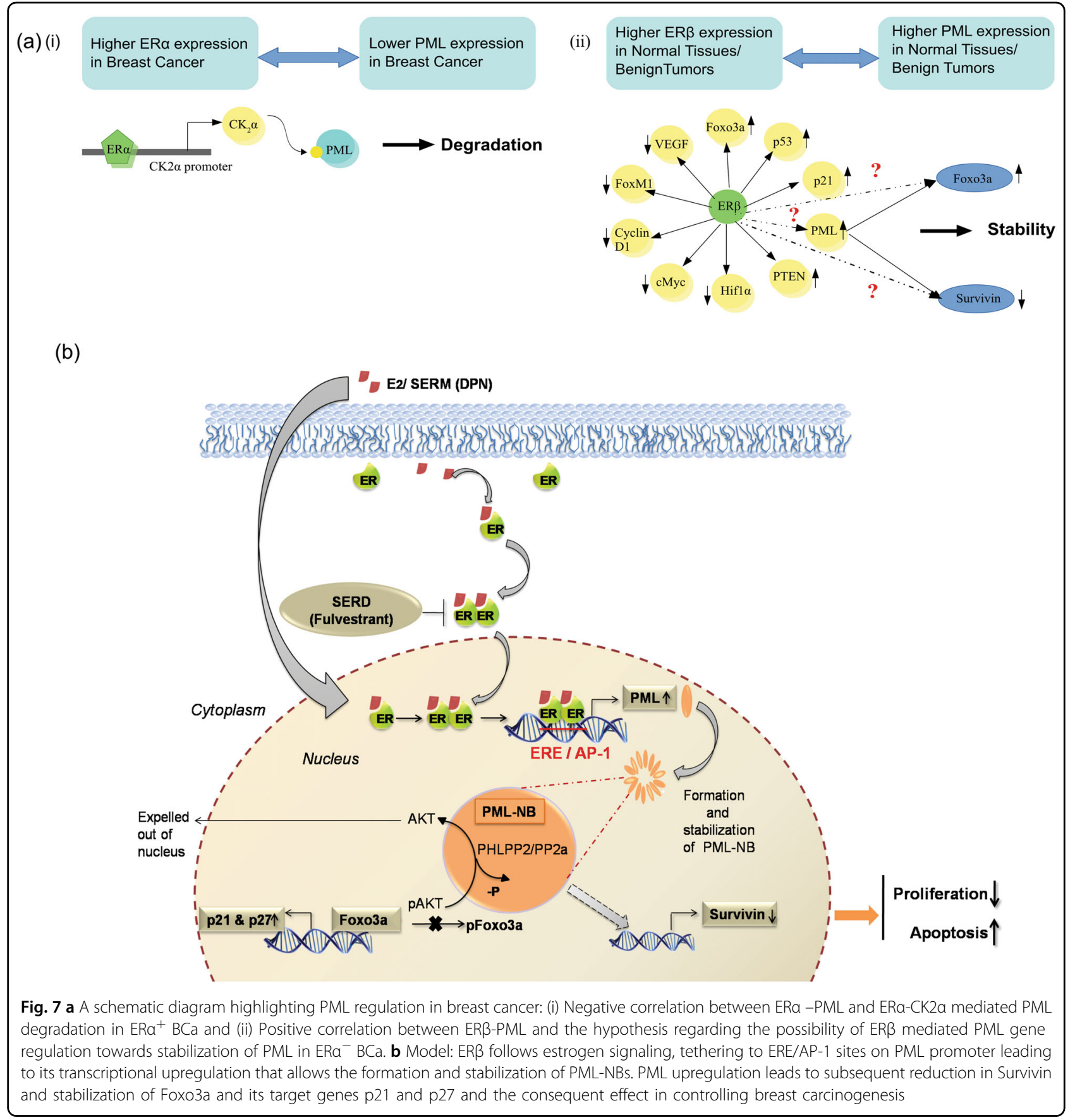

Mutation studies proved that ER $\beta$ directly associates with PML promoter via its DNA binding domain and tethers to both ERE and AP-1 sites. Additionally, ER $\beta$ binding on ERE sites provides more impetus for PML promoter activity, as compared to the AP- 1 sites. Moreover, ER $\beta$ action through AP-1 sites is complicated and is reported to be ligand specific $^{34,42,47}$, further analysis and validation of which would make the study interesting. It was intriguing to decipher what roles a stabilized PML hold in regulating tumor suppression via its effector molecules, namely
Foxo3a and Survivin. We observed a strong positive correlation of ER $\beta$-PML with Foxo3a and a negative correlation with Survivin, observed both at protein and mRNA levels, in human breast tumors and normal tissues. PML knockdown abolishes Foxo3a expression and causes an increase in expression of Survivin, the results being reversed on introduction of ER $\beta$. A stabilized Foxo3a in lieu of the ER $\beta$-PML network is able to transcriptionally activate its target gene promoters p21 and p27, leading to increase in their expression. 
In summary, our work thus establishes a compelling link in controlling oncogenesis where tumor suppressor PML is regulated by a pro-apoptotic molecule ER $\beta$. ER $\beta$ binds to estrogen or to several ER $\beta$ specific Selective Estrogen Receptor Modulators (SERMs) ${ }^{47,48}$ such as DPN, WAY-202196, WAY-200070, 8b-VE2 $2^{49,50}$ and activate signaling. On the other hand, Selective Estrogen Receptor Downregulators (SERDs) such as Fulvestrant (ICI 182,780) inhibit receptor dimerization and accelerate ER degradation, thus providing pure anti-estrogenic effect $^{24,51,52}$. Activated ER $\beta$ tethers to ERE/AP-1 sites on PML promoter and switches on its transcriptional upregulation. Stabilized PML further controls oncogenesis using bi-fold method: (a) by down-regulating pro-oncogenic Survivin and (b) by acting as a scaffold molecule, causing possible inactivation of active pAKT and thus stabilization of Foxo3a that further activates important cell cycle regulators and markers of tumor suppression: p21 and p27. Thus ER $\beta$-PML network interestingly curbs oncogenesis by inhibition of anti-apoptotic molecule and stabilizing a tumor-suppressor (Fig. 7b). Exploration of this novel 'ER $\beta$-PML-(Foxo3a/Survivin)' signaling axis might hopefully provide a new direction in the clinical management of breast cancer. This work can also consider $\operatorname{ER} \beta$ as a therapeutic target in $E R \alpha^{-}$tumors thus helping us to develop a new therapeutic network.

\section{Material and methods}

\section{Human breast tissue samples}

Formalin-fixed paraffin-embedded sections, derived from post-surgical human $\mathrm{BCa}(n=35)$, TNBC $(n=19)$ and adjacent normal breast $(n=24)$ tissues collected from Indian patients were used in this study. The samples were collected in accordance with all medical and ethical regulations, including patient consent, and with formal approval from the institutional ethical committees of both CSIR-IICB and Park Clinic (source of normal and BCa samples).

\section{Histological analysis and immunohistochemistry (IHC)}

Histological and Immunohistochemical studies were conducted as described before ${ }^{29,53}$. For image scoring purposes, an overall $\mathrm{H}$-score ${ }^{54}$ ranging from 100 to 300 was achieved where the degree of staining $(0-100 \%)$ was multiplied by intensity pattern of staining (set at 1 : negative or weak, 2: moderate and 3: strong). The slides were viewed and images captured at $\times 200$ and $\times 400$ magnifications by EVOS XL Cell Imaging System (Life Technologies-Thermo Fischer Scientific).

\section{Expression plasmids}

ER $\beta$ was sub-cloned from pcDNA nv5 vector (purchased from Addgene \#22770) to pGZ21dx (referred here as GFP-ER $\beta$ ) and pcDNA $3.1(+/+)$ (referred to as WTER $\beta$ or ER $\beta$ ) vectors. Human $(-1447$ to +250$)$ and mouse ( -800 to TSS) PML promoters were PCR amplified using genomic DNA from HEK293 cells and 4T1 cells respectively and cloned into pGL3 basic vector. WWP-p21/ Waf1-Luc was purchased from Addgene (\#16451) and pGVB2-p27Kip1-Luc promoter was a kind gift to our lab from Dr. Toshiyuki Sakai; Kyoto Prefectural University of Medicine, Japan. pSG5-PML3, encoding PML isoform IV (according to nomenclature established by Jensen, Shiels and Freemont ${ }^{55}$ ), was a kind gift from Dr. Paul S Freemont; Division of Molecular Biosciences, Imperial College of London, UK. HA-FOXO3a WT was purchased from Addgene (\#1787). siRNAs against PML (sc-36284) and ER $\beta$ (sc-35325, sc-44297) were purchased from Santa Cruz Biotechnology.

\section{Cell culture, transfections and treatments}

HEK293 and human TNBC cell lines MDA MB 231, MDA MB 468 and MDA MB 453 were maintained in Dulbecco's Modified Eagle's Medium (DMEM) and mouse BCa cell line 4T1 in RPMI medium (Invitrogen), supplemented with 10\% fetal bovine serum (FBS, Gibco) using standard procedures. Transfections were carried out with either Lipofectamine 2000 (for DNA constructs) or with Lipofectamine RNAimax (for siRNAs) (both of Life Technologies) following manufacturer's protocol. For transfecting siRNA against ER $\beta$, equal amount of both the siRNAs are used in combination to knock down ER $\beta$. Transfection of plasmids was followed upto $24 \mathrm{hr}$ prior to any addition of drug, while siRNA transfections were performed upto $48 \mathrm{hr}$.

For estrogen free experiments, the cells were cultured and maintained in phenol red-free DMEM (Invitrogen) supplemented with 5\% charcoal stripped FBS (Invitrogen) as described before ${ }^{31}$. The ER $\beta$ specific ligand 2,3-Bis(4hydroxyphenyl) propionitrile (DPN) and ER antagonist ICI 182,780 (Fulvestrant/ICI) were purchased from Sigma and were used at concentration of $10 \mathrm{nM}$ and $1 \mu \mathrm{M}$, respectively, for $24 \mathrm{hr}$, unless otherwise mentioned. Transcriptional inhibitor Actinomycin D (Sigma) was used at a concentration of $10 \mu \mathrm{g} / \mathrm{ml}$ for $4 \mathrm{hr}$.

\section{Site directed mutagenesis (SDM) and deletion}

Deletions of half ERE sites and AP1 sites in human PML promoter were performed using QuickChange XL SiteDirected Mutagenesis kit (Agilent Technologies) ${ }^{56}$. The mutated promoters were further cloned into pGL3 basic vector. The ER $\beta$ DNA binding domain, comprising amino acids 144-225 was deleted and the mutated ER $\beta$ DNA was cloned into pcDNA 3.1 vector. All the constructs were verified by sequencing. Sequences of the primers are given in Additional file 1. 


\section{Immunblotting (IB)}

Preparation of whole cell lysates and IB analyses were performed as described before ${ }^{57}$. The following primary antibodies were used: ER $\beta$ (sc-8974), PML (sc-5621), p21 (sc-53870), Actin (sc-1616), and GFP (sc-9996) (SantaCruz Biotechnology); Foxo3a (ab53287), p-Foxo3a (S253) (ab31109) (Abcam); Survivin (\#2808), Bim (\#2819), Bax (\#2772), cleaved PARP (\#9625) and cleaved Caspase 3 (\#9664) (Cell Signalling Technology); HRP-tagged antirabbit and anti-mouse secondary antibodies (Cell Signalling Technology); HRP-tagged anti-goat secondary antibody (Sigma-Aldrich). Densitometry values of the immunoblots were computed using GelQuant.Net software.

\section{RNA preparation and quantitative real time PCR}

Total RNA was extracted by using Trizol reagent (Invitrogen) as per the manufacturer's protocol. cDNA was prepared and Real-time PCR performed by using FastSYBR Green Master Mix (Applied Biosystems) in Via7 Real-Time PCR Instrument (Applied Biosystems) as described before ${ }^{56}$. Sequences of the primers are given in Additional file 1.

\section{Luciferase assay}

Luciferase assays were performed as described before ${ }^{58}$. All experiments for luciferase assays were followed upto $48 \mathrm{~h}$ post transfection and $24 \mathrm{hr}$ for any additional drug treatment. A minimum of three biological repeat experiments along with three technical repeats each were conducted to empirically determine the quantifications.

\section{Chromatin Immunoprecipitation (ChIP) Assay}

ChIP assay was conducted as described previously ${ }^{59}$. In brief, the cells were subjected to crosslinking with $0.8 \%$ formaldehyde, reaction quenched with $125 \mathrm{mM}$ glycine and further sonicated to an average size of 500-800 bp. In total $10 \%$ of pre-cleared sonicated chromatin (unless otherwise mentioned) was kept aside as Input and the rest was incubated overnight with $2 \mu \mathrm{g}$ each of primary antibodies against either ER $\beta$, Polymerase II or normal rabbit IgG (purchased from Cell Signaling Technologies) and further pulled-down with pre-blocked protein A Sepharose beads. The precipitated chromatin was eluted from the beads and de-crosslinked. DNA was purified from immunoprecipitated chromatin fragments and PCR amplified using Qiagen's Top Taq master mix. The PCR products were either run on a $1 \%$ agarose gel (for endogenous ER $\beta$ binding), or subjected to a quantitative RTPCR using SYBR Green master mix. PCR cycling conditions are as follows: one cycle at $94{ }^{\circ} \mathrm{C}$ for $5 \mathrm{~min}, 40$ cycles at $95^{\circ} \mathrm{C}$ for $30 \mathrm{~s}, 54.4{ }^{\circ} \mathrm{C}$ for $30 \mathrm{~s}$, and at $72{ }^{\circ} \mathrm{C}$ for $30 \mathrm{~s}$, followed by one final cycle at $72{ }^{\circ} \mathrm{C}$ for $10 \mathrm{~min}$.

\section{Cell viability and wound healing assays}

Cell viability assay using MTT and wound healing (scratch) assay on $70-80 \%$ confluent monolayer cells were conducted as described before ${ }^{57}$.

\section{Survival assay}

The cells $\left(2.5 \times 10^{3}\right)$ in triplicate were treated with DMSO or DPN for $24 \mathrm{hr}$ in $5 \%$ charcoal stripped serum containing media. After treatment, the cells were grown for another 15 days in complete medium. Assay was performed as described before ${ }^{60}$.

\section{Caspase $3 / 7$ assay}

MDA MB 468 cells were plated in 96-well plates (in triplicate), and treated with DMSO or DPN for $24 \mathrm{hr}$. Caspase-Glo 3/7 Reagent(Caspase-Glo ${ }^{\circledR}$ 3/7 Assay, Promega) was added to the wells and luminescence recorded after $30 \mathrm{~min}$ and also after $1.5 \mathrm{hr}$, following manufacturer's instructions.

\section{Immuno-fluorescence microscopy}

MDA MB 468 cells were seeded over sterile cover slips placed inside $35 \mathrm{~mm}$ tissue culture dishes and cultured as per prescribed condition, or as mentioned above, to a confluency of $60 \%$. The cells were harvested as follows: $4 \%$ paraformaldehyde fixation, $0.5 \%$ Triton-X-100 permeabilization and blocking with $2.5 \%$ BSA in PBS. Standard protocol of immuno-staining was followed and the cells were stained with primary antibodies, ER $\beta$ (Abcam ab288) and PML (Abcam ab53773) and fluorochrome-conjugated secondary antibodies (Alexa-Fluor 488 or 594). 4, 6diamino-2-phenylindole (DAPI) was used as nuclear counter stain. All slides were viewed and images captured at $\times 120$ using FluoView FV10i confocal laser scanning microscope (Olympus Life Science).

\section{Cell cycle analysis}

MDA MB 468 cells were transfected as mentioned in the figures for the requisite durations as mentioned above, and harvested using Trypsin. The cells were ethanol (70\%) fixed and further processed for cell-cycle analysis as described before ${ }^{57}$ and analyzed in BD LSR-Fortessa using FACS-Diva software (BD Biosciences).

\section{Statistical analyses}

Paired Student's $t$-test was employed to determine the significance value in all experiments. The significance is presented as $* P 0.05, * P 0.005$ and $* * 0001$, and nonsignificant differences are presented as NS. The differences in $\mathrm{H}$-score values of all the concerned proteins between normal breast and $\mathrm{BCa}$ tissues were analyzed by Mann-Whitney Utest. All statistical analyses were performed using either SPSS (IBM) or GraphPad QuickCals software packages. 


\section{Acknowledgements}

We are sincerely thankful to Dr. Toshiyuki Sakai; Department of MolecularTargeting Cancer Prevention, Graduate School of Medical Science, Kyoto Prefectural University of Medicine, Kyoto, Japan, for kindly gifting us with the pGVB2-p27Kip1-Luc promoter construct. We are thankful to Dr. Paul S. Freemont; Division of Molecular Biosciences, Imperial College of London, UK, for kindly gifting us with PSG5-PML construct. We are also thankful to Dr. Suresh Bajoria, NH-RN Tagore Hospital, Kolkata for human ethical clearance and clinical sample \& data management. This work is supported by grants from DST-Nano Mission (DST/NM/NT/2018/105(G) \& DST-SERB (EMR/2017/000992 \& EMR/2017/001183) and CSIR, Govt. of India to the corresponding author Dr. Mrinal K. Ghosh.

\section{Authors' contributions}

N.D. and M.K.G. conceived, designed and coordinated the study. U.C., S.C., M.S. I., and C.K.P. provided the tissue samples and reagents. N.D. performed all the experiments. M.K.G. and N.D. analyzed and interpreted the data and wrote the manuscript.

\section{Author details}

${ }^{1}$ Cancer Biology and Inflammatory Disorder Division, Council of Scientific and Industrial Research-Indian Institute of Chemical Biology (CSIR-IICB), TRUE Campus, CN-6, Sector-V, Salt Lake, Kolkata-700091 \& 4, Raja S.C. Mullick Road, Jadavpur, Kolkata 700032, India. ²Department of Oncogene Regulation, Chittaranjan National Cancer Institute, 37, S.P. Mukherjee Road, Kolkata 700026, India. ${ }^{3}$ Division of Neurosurgery, Division of Pathology, Park Clinic, 4, Gorky Terrace, Kolkata 700017, India

\section{Data availability}

The data supporting the conclusion of this study are included within this manuscript and the Supplementary files.

\section{Conflict of interest}

The authors declare that they have no conflict of interest.

\section{Ethics approval and consent to participate}

Samples were collected following the ethical committee guidelines of CSIRIICB and Park Clinic. Patient consents were taken for acquiring the samples after explaining them the nature and possible consequences of the experiments and publishing the research outcome.

\section{Publisher's note}

Springer Nature remains neutral with regard to jurisdictional claims in published maps and institutional affiliations.

Supplementary Information accompanies this paper at (https://doi.org/ 10.1038/s41419-019-1889-2).

Received: 13 February 2019 Revised: 24 June 2019 Accepted: 11 July 2019 Published online: 10 September 2019

\section{References}

1. Bernardi, R. \& Pandolfi, P. P. Structure, dynamics and functions of promyelocytic leukaemia nuclear bodies. Nat. Rev. Mol. Cell Biol. 8, 1006-1016 (2007).

2. Gurrieri, C. et al. Loss of the tumor suppressor PML in human cancers of multiple histologic origins. J. Natl Cancer Inst. 96, 269-279 (2004).

3. Cheng, X. \& Kao, H.-Y. Post-translational modifications of PML: consequences and implications. Front. Oncol. 2, 210 (2013).

4. Stadler, M. et al. Transcriptional induction of the PML growth suppressor gene by interferons is mediated through an ISRE and a GAS element. Oncogene 11, 2565-2573 (1995).

5. Lavau, C. et al. The acute promyelocytic leukaemia-associated PML gene is induced by interferon. Oncogene 11, 871-876 (1995).
6. Cheng, X. \& Kao, H.-Y. Microarray analysis revealing common and distinct functions of promyelocytic leukemia protein (PML) and tumor necrosis factor alpha (TNFa) signaling in endothelial cells. BMC Genomics 13, 453 (2012).

7. Kim, T.K. et al. Direct transcriptional activation of promyelocytic leukemia protein by IFN regulatory factor 3 Induces the p53-dependent growth inhibition of cancer cells. Cancer Res. 67, 11133-11140 (2007).

8. Hubackova, S., Krejcikova, K., Bartek, J. \& Hodny, Z. Interleukin 6 signaling regulates promyelocytic leukemia protein gene expression in human normal and cancer cells. J. Biol. Chem. 287, 26702-26714 (2012).

9. Ferbeyre, G. et al. PML is induced by oncogenic ras and promotes premature senescence. Genes Dev. 14, 2015-2027 (2000).

10. de Stanchina, E. et al. PML is a direct p53 target that modulates p53 effector functions. Mol. Cell 13, 523-535 (2004).

11. Ghoncheh, M., Pournamdar, Z. \& Salehiniya, H. Incidence and mortality and epidemiology of Breast Cancer in the World. Asian Pac. J. Cancer Prev. 17, 43-46 (2016)

12. Yao, $\mathrm{H}$. et al. Triple-negative breast cancer: is there a treatment on the horizon? Oncotarget 8, 1913-1924 (2016).

13. Ma, C. X., Sanchez, C. G. \& Ellis, M. J. Predicting endocrine therapy responsiveness in breast cancer. Oncol. Williston Park N. 23, 133-142 (2009).

14. Sieuwerts, A. M. et al. Evaluation of the ability of adjuvant tamoxifen-benefit gene signatures to predict outcome of hormone-naive estrogen receptorpositive breast cancer patients treated with tamoxifen in the advanced setting. Mol. Oncol. 8, 1679-1689 (2014).

15. Dotzlaw, H., Leygue, E., Watson, P. H. \& Murphy, L. C. Expression of estrogen receptor-beta in human breast tumors. J. Clin. Endocrinol. Metab. 82 2371-2374 (1997).

16. Speirs, V. et al. Oestrogen receptor $\beta$ : what it means for patients with breast cancer. Lancet Oncol. 5, 174-181 (2004).

17. Lazennec, G., Bresson, D., Lucas, A., Chauveau, C. \& Vignon, F. ERß inhibits proliferation and invasion of breast cancer cells. Endocrinology 142, 4120-4130 (2001).

18. Haldosén, L.-A., Zhao, C. \& Dahlman-Wright, K. Estrogen receptor beta in breast cancer. Mol. Cell. Endocrinol. 382, 665-672 (2014).

19. Fox, E. M., Davis, R. J. \& Shupnik, M. A. ERß in breast cancer - onlooker, passive player, or active protector? Steroids 73, 1039-1051 (2008).

20. Bardin, A. Loss of ER expression as a common step in estrogen-dependent tumor progression. Endocr. Relat. Cancer 11, 537-551 (2004).

21. Meyers, M. J. et al. Estrogen receptor-beta potency-selective ligands: structureactivity relationship studies of diarylpropionitriles and their acetylene and polar analogues. J. Med. Chem. 44, 4230-4251 (2001).

22. Maggi, A. Liganded and unliganded activation of estrogen receptor and hormone replacement therapies. Biochim. Biophys. Acta 1812, 1054-1060 (2011).

23. Paruthiyil, S. et al. Estrogen receptor $\beta$ inhibits human breast cancer cell proliferation and tumor formation by causing a G2 cell cycle arrest. Cancer Res. 64, 423-428 (2004)

24. Wakeling, A. E., Dukes, M. \& Bowler, J. A potent specific pure antiestrogen with clinical potential. Cancer Res. 51, 3867-3873 (1991).

25. Song, W. et al. Targeting newly identified ER//TGF- $31 /$ SMAD3 signals with the FDA-approved anti-estrogen Faslodex or an ERß selective antagonist in renal cell carcinoma. Mol. Oncol. 12, 2055-2071 (2018).

26. Osborne, C. K., Wakeling, A. \& Nicholson, R. I. Fulvestrant: an oestrogen receptor antagonist with a novel mechanism of action. Br. J. Cancer 90, S2-S6 (2004).

27. Björnström, L. \& Sjöberg, M. Mutations in the estrogen receptor DNA-binding domain discriminate between the classical mechanism of action and crosstalk with Stat5b and activating protein 1 (AP-1). J. Biol. Chem. 277, 48479-48483 (2002).

28. Thomas, C. \& Gustafsson, J.-A. The different roles of ER subtypes in cancer biology and therapy. Nat. Rev. Cancer 11, 597-608 (2011)

29. Chatterjee, A., Chatterjee, U. \& Ghosh, M. K. Activation of protein kinase CK2 attenuates FOXO3a functioning in a PML-dependent manner: implications in human prostate cancer. Cell Death Dis. 4, e543 (2013).

30. $\mathrm{Xu}, \mathrm{Z} . \mathrm{X}$. et al. Promyelocytic leukemia protein 4 induces apoptosis by inhibition of survivin expression. J. Biol. Chem. 279, 1838-1844 (2004).

31. Das, N., Datta, N., Chatterjee, U. \& Ghosh, M. K. Estrogen receptor alpha transcriptionally activates casein kinase 2 alpha: a pivotal regulator of promyelocytic leukaemia protein (PML) and AKT in oncogenesis. Cell. Signal. 28, 675-687 (2016). 
32. Scaglioni, P. P. et al. A CK2-dependent mechanism for degradation of the PML tumor suppressor. Cell 126, 269-283 (2006).

33. Hartman, J. et al. Tumor repressive functions of estrogen receptor in SW480 colon cancer cells. Cancer Res. 69, 6100-6106 (2009).

34. Liu, M.-M. et al. Opposing action of estrogen receptors $\alpha$ and $\beta$ on cyclin D1 gene expression. J. Biol. Chem. 277, 24353-24360 (2002).

35. Mak, P. et al. ERß impedes prostate cancer EMT by destabilizing HIF-1a and inhibiting VEGF-mediated snail nuclear localization: implications for gleason grading. Cancer Cell 17, 319-332 (2010).

36. Lim, W. et al. Estrogen receptor beta inhibits transcriptional activity of hypoxia inducible factor-1 through the downregulation of arylhydrocarbon receptor nuclear translocator. Breast Cancer Res. 13, R32 (2011).

37. Horimoto, Y. et al. ERß1 represses FOXM1 expression through targeting ERa to control cell proliferation in breast cancer. Am. J. Pathol. 179, 1148-1156 (2011).

38. Solakidi, S., Psarra, A.-M. G. \& Sekeris, C. E. Differential subcellular distribution of estrogen receptor isoforms: localization of ERa in the nucleoli and ERß in the mitochondria of human osteosarcoma SaOS-2 and hepatocarcinoma HepG2 cell lines. Biochim. Biophys. Acta 1745, 382-392 (2005).

39. Kocanova, S., Mazaheri, M., Caze-Subra, S. \& Bystricky, K. Ligands specify estrogen receptor alpha nuclear localization and degradation. BMC Cell Biol. 11, 98 (2010).

40. Chang, E. C., Frasor, J., Komm, B. \& Katzenellenbogen, B. S. Impact of estrogen receptor beta on gene networks regulated by estrogen receptor alpha in breast cancer cells. Endocrinology 147, 4831-4842 (2006).

41. Williams, C., Edvardsson, K., Lewandowski, S. A., Ström, A. \& Gustafsson, J.-A. A genome-wide study of the repressive effects of estrogen receptor beta on estrogen receptor alpha signaling in breast cancer cells. Oncogene 27, 1019-1032 (2008).

42. Pak, T. R. et al. The androgen metabolite, $5 a-A n d r o s t a n e-3 \beta, 17 \beta-D i o l$, is a potent modulator of estrogen receptor- $\beta 1$-mediated gene transcription in neuronal cells. Endocrinology 146, 147-155 (2005).

43. Mott, N. N. \& Pak, T. R. Characterisation of human oestrogen receptor beta (ERß) splice variants in neuronal cells. J. Neuroendocrinol. 24, 1311-1321 (2012).

44. Hall, J. M. \& McDonnell, D. P. The estrogen receptor beta-isoform (ERbeta) of the human estrogen receptor modulates ERalpha transcriptional activity and is a key regulator of the cellular response to estrogens and antiestrogens. Endocrinology 140, 5566-5578 (1999).

45. Tremblay, A., Tremblay, G. B., Labrie, F. \& Giguère, V. Ligand-independent recruitment of SRC-1 to estrogen receptor beta through phosphorylation of activation function AF-1. Mol. Cell 3, 513-519 (1999).

46. Mclnerney, E. M., Weis, K. E., Sun, J., Mosselman, S. \& Katzenellenbogen, B. S. Transcription activation by the human estrogen receptor subtype beta (ER beta) studied with ER beta and ER alpha receptor chimeras. Endocrinology 139, 4513-4522 (1998).

47. Paech, K. et al. Differential ligand activation of estrogen receptors ERa and ERß at AP1 sites. Science 277, 1508-1510 (1997).

48. Paterni, I., Granchi, C., Katzenellenbogen, J. A. \& Minutolo, F. Estrogen Receptors Alpha (ERa) and Beta (ERß): subtype-selective ligands and clinical potential. Steroids 0, 13-29 (2014).

49. Carroll, V. M., Jeyakumar, M., Carlson, K. E. \& Katzenellenbogen, J. A. Diarylpropionitrile (D. P. N.) enantiomers: synthesis and evaluation of estrogen receptor beta-selective ligands. J. Med. Chem. 55, 528-537 (2012).

50. Deroo, B. J. \& Buensuceso, A. V. Minireview: estrogen receptor- $\beta$ : mechanistic insights from recent studies. Mol. Endocrinol. 24, 1703-1714 (2010).

51. Carlson, R. W. The history and mechanism of action of fulvestrant. Clin. Breast Cancer 6, S5-S8 (2005).

52. Howell, S. J., Johnston, S. R. D. \& Howell, A. The use of selective estrogen receptor modulators and selective estrogen receptor down-regulators in breast cancer. Best. Pract. Res. Clin. Endocrinol. Metab. 18, 47-66 (2004).

53. Sarkar, M., Khare, V., Guturi, K. K. N., Das, N. \& Ghosh, M. K. The DEAD box protein p68: a crucial regulator of AKT/FOXO3a signaling axis in oncogenesis. Oncogene 34, 5843-5856 (2015).

54. Choudhury, K. R., Yagle, K. J., Swanson, P. E., Krohn, K. A. \& Rajendran, J. G. A robust automated measure of average antibody staining in immunohistochemistry images. J. Histochem. Cytochem. 58, 95-107 (2010).

55. Jensen, K., Shiels, C. \& Freemont, P. S. PML protein isoforms and the RBCC/ TRIM motif. Oncogene 20, 7223 (2001).

56. Sarkar, M., Khare, V. \& Ghosh, M. K. The DEAD box protein p68: a nove coactivator of Stat3 in mediating oncogenesis. Oncogene 36, 3080-3093 (2017).

57. Ahmed, S. F. et al. Exosome-mediated delivery of the intrinsic C terminus domain of PTEN protects it from proteasomal degradation and ablates tumorigenesis. Mol. Ther. J. Am. Soc. Gene Ther. 23, 255-269 (2015).

58. Bhattacharya, S. \& Ghosh, M. K. HAUSP regulates C-MYC expression via deubiquitination of TRRAP. Cell. Oncol. Dordr. 38, 265-277 (2015).

59. Guturi, K. K. N. et al. Mechanism of $\beta$-catenin-mediated transcriptional regulation of epidermal growth factor receptor expression in glycogen synthase kinase 3 $\beta$-inactivated prostate cancer cells. J. Biol. Chem. 287, 18287-18296 (2012).

60. Dey, P., Ström, A., GustafssonJ.å. Estrogen receptor $\beta$ upregulates FOXO3a and causes induction of apoptosis through PUMA in prostate cancer. Oncogene 33, 4213-4225 (2014). 